\title{
Longitudinal Metabolomics of Human Plasma Reveals Robust Prognostic Markers of COVID-19 Disease Severity
}

Miriam Sindelar ${ }^{1,2,3}$, Ethan Stancliffe ${ }^{1,2,3}$, Michaela Schwaiger-Haber ${ }^{1,2,4}$, Dhanalakshmi S.

Anbukumar ${ }^{1,2,4}$, Randy A. Albrecht ${ }^{5,6}$, Wen-Chun Liu ${ }^{5,6,7}$, Kayla Adkins Travis ${ }^{8}$, Adolfo García-

Sastre $^{5,6,9,10}$, Leah P. Shriver ${ }^{1,2}$, Gary J. Patti ${ }^{1,2,11,12}$

\author{
${ }^{1}$ Department of Chemistry, Washington University, St. Louis, MO \\ ${ }^{2}$ Department of Medicine, Washington University, St. Louis, MO \\ ${ }^{3}$ These authors contributed equally \\ ${ }^{4}$ These authors contributed equally \\ ${ }^{5}$ Department of Microbiology, Icahn School of Medicine at Mount Sinai, New York City, NY \\ ${ }^{6}$ Global Health and Emerging Pathogens Institute, Icahn School of Medicine at Mount Sinai, New York City, NY \\ ${ }^{7}$ Current affiliation: Biomedical Translation Research Center, Academia Sinica, Taipei, 11571, Taiwan \\ ${ }^{8}$ Department of Chemistry, University of Akron, Akron, OH \\ ${ }^{9}$ Department of Medicine, Division of Infectious Diseases, Icahn School of Medicine at Mount Sinai, New York \\ City, NY \\ ${ }^{10}$ The Tisch Cancer Institute, Icahn School of Medicine at Mount Sinai, New York City, NY \\ ${ }^{11}$ Siteman Cancer Center, Washington University, St. Louis, MO \\ ${ }^{12}$ To whom correspondence should be addressed: gjpattij@wustl.edu
}

Abstract: There is an urgent need to identify which COVID-19 patients will develop lifethreatening illness so that scarce medical resources can be optimally allocated and rapid treatment can be administered early in the disease course, when clinical management is most effective. To aid in the prognostic classification of disease severity, we performed untargeted metabolomics profiling of 341 patients with plasma samples collected at six longitudinal time points. Using the temporal metabolic profiles and machine learning, we then built a predictive model of disease severity. We determined that the levels of 25 metabolites measured at the time of hospital admission successfully predict future disease severity. Through analysis of longitudinal samples, we confirmed that these prognostic markers are directly related to disease progression and that their levels are restored to baseline upon disease recovery. Finally, we validated that these metabolites are also altered in a hamster model of COVID-19. Our results indicate that metabolic changes associated with COVID-19 severity can be effectively used to stratify patients and inform resource allocation during the pandemic. 
medRxiv preprint doi: https://doi.org/10.1101/2021.02.05.21251173; this version posted February 8, 2021. The copyright holder for this preprint (which was not certified by peer review) is the author/funder, who has granted medRxiv a license to display the preprint in perpetuity.

It is made available under a CC-BY-ND 4.0 International license .

\section{Introduction}

Coronavirus disease 2019 (COVID-19), which is caused by infection with the novel coronavirus SARS-CoV-2, has led to a global health crisis (Wu et al., 2020b). As of January 2021, more than 100 million cases of COVID-19 have been reported worldwide and resulted in over 2.1 million deaths (2020d). The infection fatality rate of SARS-CoV-2 can be reduced with the appropriate care (e.g., intensive care unit beds, staff, extracorporeal life support, and therapeutics). Such resources are limited, however, and with fewer than five million individuals in the United States fully vaccinated, they continue to be in high demand (2020d). In the United States, one out of five hospitals with an intensive care unit (ICU) has at least $95 \%$ of their ICU beds full (Conlen F., 2021) and fewer than 150,000 patient courses of casirivimab and imdevimab monoclonal antibodies have been distributed (2020c). Availability of bamlanivimab, the only other monoclonal antibody that currently has emergency use authorization, has been similarly limited (2020b).

To reduce mortality, patients who develop critical illness from COVID-19 must be treated early in the disease course before the onset of severe symptoms (Kim et al., 2020).

Unfortunately, COVID-19 progresses rapidly and it is currently difficult to determine which subset of infected patients will develop life-threatening disease (Kattan et al., 2020). If these patients could be identified, however, then the limited amount of resources available could be optimally allocated to save the greatest number of lives. To this end, the objective of the current study was to identify metabolites in patient plasma that accurately predict life-threatening cases of COVID-19 prior to the onset of severe symptoms.

SARS-CoV-2 is an enveloped, single-stranded positive-sense RNA virus that gains entry into host cells through binding of the viral S protein to the angiotensin-converting enzyme 2 (ACE2) receptor (Hou et al., 2020; Zhang et al., 2020). Multiple studies have established that patients 
medRxiv preprint doi: https://doi.org/10.1101/2021.02.05.21251173; this version posted February 8, 2021. The copyright holder for this preprint (which was not certified by peer review) is the author/funder, who has granted medRxiv a license to display the preprint in perpetuity.

It is made available under a CC-BY-ND 4.0 International license .

60 infected with SARS-CoV-2 have metabolic dysregulation, possibly due to immune-triggered

61 inflammation or other changes in host physiology (Fraser et al., 2020; Kimhofer et al., 2020;

62 Overmyer et al., 2020; Shen et al., 2020; Thomas et al., 2020; Wu et al., 2020a). To date,

63 however, unique alterations in metabolites upon SARS-CoV-2 infection have not been validated

64 in large patient cohorts. Moreover, metabolites have not been profiled longitudinally from early

65 after infection through recovery to assess which changes are indicative of disease course.

In this study, we performed untargeted metabolomics profiling on the polar and non-polar

67

68

69

70

71

72

73

74

75

76

77

78

79

80 fractions of over 700 human plasma samples collected from 341 patients as part of the WU-350

cohort recruited during the first phase of the pandemic in St. Louis, MO. Untargeted

metabolomics allows for the unbiased profiling of the human metabolome (Patti et al., 2012) and

has been successful at discovering metabolite biomarkers associated with disease pathology

(Beger et al., 2016). Using machine learning, we built a predictive model of COVID-19 disease

severity based on the metabolic profiles of samples collected from patients at hospital

presentation. The model led us to identify 25 unique metabolite biomarkers that were highly

predictive of future disease severity. We confirmed that these metabolites were directly related to

SARS-CoV-2 infections through comparison to patient demographics, comorbidities, clinical

measurements, and longitudinal samples taken from individuals over the course of disease

progression. Lastly, we validated that the same biomarkers appeared in an established hamster

model of SARS-CoV-2 infection (Chan et al., 2020; Imai et al., 2020; Muñoz-Fontela et al., 2020). 
medRxiv preprint doi: https://doi.org/10.1101/2021.02.05.21251173; this version posted February 8, 2021. The copyright holder for this preprint (which was not certified by peer review) is the author/funder, who has granted medRxiv a license to display the preprint in perpetuity.

It is made available under a CC-BY-ND 4.0 International license .

\section{Results}

\section{Clinical cohort $W U-350$ - demographics}

The clinical cohort presented in this study consisted of 155 female and 186 male participants. Out of the 341 patients, 274 tested positive for SARS-CoV-2 by nasopharyngeal swab PCR and 67 tested negative. The demographic information for the patients is summarized in Table 1 . Significant differences were observed in several demographic factors for the SARS-CoV-2positive $(\mathrm{COV}+)$ cohort compared to the SARS-CoV-2-negative $(\mathrm{COV}-)$ cohort. The age ranges of both the $\mathrm{COV}+$ and COV- cohorts are comparable (Figure S1a). However, the COV+ group has significantly older study participants $(\mathrm{p}<0.0001)$. The COV+ group is also enriched for African American, male, and non-smoking individuals. There was no significant difference in the body mass index (BMI) between the two groups (Figure S1b).

Out of $274 \mathrm{COV}+$ individuals, 253 were admitted to the hospital and 129 of those patients were admitted to the ICU. As expected, the incidence of both factors (hospitalization and ICU admission), were significantly increased in the COV+ cohort. Treatment of severe COVID-19 cases often results in intubation and mechanical ventilation (Goyal et al., 2020). In total, 49 of the $\mathrm{COV}+$ patients required mechanical ventilation, whereas only four COV-individuals required mechanical ventilation. The mortality rate in the $\mathrm{COV}+$ group was $19 \%$, which was significantly higher than in the COV-group (6.0\%). A total of $52 \mathrm{COV}+$ patients died, with 48 of the deaths being attributed to COVID-19 and 4 being attributed to other causes.

Out of $274 \mathrm{COV}+$ patients, 253 showed at least one COVID-19-related symptom mentioned by the Centers for Disease Control and Prevention (CDC) including fever, chills, conjunctival congestion, nasal congestion, headaches, cough, sore throat, shortness of breath, nausea or vomiting, diarrhea, myalgia, fatigue, and loss of taste or smell (CDC, 2020). The remaining 21 
$104 \mathrm{COV}+$ cases showed none of these symptoms and were classified as COVID-19-asymptomatic.

105 Patients without COVID-19 symptoms received a SARS-CoV-2-test upon presentation at the

106 hospital for reasons unrelated to the pandemic (e.g., accidents, trauma, routine procedures, pre-

107 operation testing, or cancer screening/treatment). Out of the $67 \mathrm{COV}$ - cases, 58 presented with at

108 least one COVID-19-related symptom, while two did not have any symptoms characteristic of

109 COVID-19. The frequency of COVID-19-related symptoms is shown in Table 1, and the

110 distributions across the $\mathrm{COV}+$ and $\mathrm{COV}$ - cohorts are depicted in Figure S1c. In both the COV-

111 and COV+ groups, the number of COVID-19 related symptoms reported per individual was

112 comparable. The breakdown of how many symptoms were experienced per individual in both the

$113 \mathrm{COV}+$ and COV-groups is shown in Figure S1d.

114 Next, we examined the distribution of comorbidities in the presented WU-350 cohort. The

115 incidence of acute respiratory failure with hypoxia and/or hypercapnia, chronic kidney disease

116 (CKD), and diabetes was significantly higher in the COV+ group compared to the COV-group

117 (Table 1). Of the COV+ patients, $43 \%$ were hypoxic at some point during their hospitalization, a

118 significantly higher proportion than in the COV-group (25\%). Furthermore, 34\% of COV+

119 individuals showed an abnormal arterial $\mathrm{pH}$ compared to $12 \%$ in the COV-group. 
medRxiv preprint doi: https://doi.org/10.1101/2021.02.05.21251173; this version posted February 8, 2021. The copyright holder for this preprint (which was not certified by peer review) is the author/funder, who has granted medRxiv a license to display the preprint in perpetuity.

It is made available under a CC-BY-ND 4.0 International license .

121 Table 1. Demographics of All Subjects ${ }^{1,2,3}$.

\begin{tabular}{|c|c|c|c|}
\hline Parameter & COV- & $\mathrm{COV}+$ & p-value \\
\hline $\mathrm{n}$ & 67 & 274 & \\
\hline Gender $(\mathrm{M} / \mathrm{F})$ & $28 / 39$ & $158 / 116$ & $\mathrm{p}=0.0193$ \\
\hline Age (yr) & $48 \pm 16$ & $60 \pm 17$ & $\mathrm{p}<0.0001$ \\
\hline Race (African American/White/other) & $32 / 35 / 0$ & $203 / 66 / 5$ & $\mathrm{p}<0.0001$ \\
\hline Body mass index & $30 \pm 8$ & $31 \pm 9$ & $\mathrm{p}=0.3518$ \\
\hline \multicolumn{4}{|l|}{ COVID-19-like symptoms } \\
\hline Any number of COVID19-like symptoms & 65 & 253 & $\mathrm{p}=0.1710$ \\
\hline Fever & 29 & 129 & $\mathrm{p}=0.5764$ \\
\hline Chills & 13 & 46 & $\mathrm{p}=0.6120$ \\
\hline Conjunctival congestion & 1 & 1 & $\mathrm{p}=0.2786$ \\
\hline Nasal congestion & 7 & 10 & $\mathrm{p}=0.0219$ \\
\hline Headache & 18 & 23 & $\mathrm{p}<0.0001$ \\
\hline Cough & 35 & 148 & $\mathrm{p}=0.7939$ \\
\hline Sore throat & 14 & 23 & $\mathrm{p}=0.0032$ \\
\hline Shortness of breath & 44 & 168 & $\mathrm{p}=0.5097$ \\
\hline Nausea or vomiting & 15 & 41 & $\mathrm{p}=0.1414$ \\
\hline Diarrhea & 11 & 38 & $\mathrm{p}=0.5939$ \\
\hline Myalgia & 16 & 66 & $\mathrm{p}=0.9717$ \\
\hline Fatigue & 21 & 54 & $\mathrm{p}=0.0393$ \\
\hline Loss of taste or smell ${ }^{4}$ & 0 & 4 & $\mathrm{p}=0.3198$ \\
\hline No COVID-19-like symptoms ${ }^{5}$ & 2 & 21 & $\mathrm{p}=0.1710$ \\
\hline \multicolumn{4}{|l|}{ Comorbidities } \\
\hline $\begin{array}{l}\text { Acute respiratory failure with hypoxia and/or } \\
\text { hypercapnia }\end{array}$ & 15 & 101 & $\mathrm{p}=0.0250$ \\
\hline Chronic kidney disease & 9 & 90 & $\mathrm{p}=0.0017$ \\
\hline Acute renal failure & 1 & 21 & $\mathrm{p}=0.0653$ \\
\hline Diabetes & 16 & 132 & $\mathrm{p}=0.0003$ \\
\hline Cancer (history/current) & $5(3 / 2)$ & $14(9 / 5)$ & $\mathrm{p}=0.5347$ \\
\hline \multicolumn{4}{|l|}{ Laboratory Results } \\
\hline Hypoxia & 17 & 117 & $\mathrm{p}=0.0092$ \\
\hline Low arterial $\mathrm{pH}$ & 5 & 72 & $\mathrm{p}<0.0001$ \\
\hline High arterial $\mathrm{pH}$ & 5 & 71 & $\mathrm{p}=0.0011$ \\
\hline Low/High arterial $\mathrm{pH}$ & 8 & 92 & $\mathrm{p}=0.0005$ \\
\hline Critically low/high arterial $\mathrm{pH}$ & 1 & 35 & $\mathrm{p}=0.0071$ \\
\hline Current smoker & $18(27 \%)$ & $34(12.4 \%)$ & $\mathrm{p}=0.0032$ \\
\hline Hospital admission $^{6}$ & $26(38.8 \%)$ & $253(92.3 \%)$ & $\mathrm{p}<0.0001$ \\
\hline ICU admission ${ }^{6}$ & $10(14.9 \%)$ & $129(47.3 \%)$ & $\mathrm{p}<0.0001$ \\
\hline Intubation and mechanical ventilation & $4(6.0 \%)$ & $49(17.9 \%)$ & $\mathrm{p}=0.0154$ \\
\hline Deceased & $4(6.0 \%)$ & $52(19.0 \%)$ & $\mathrm{p}=0.0097$ \\
\hline Deceased because of COVID-19 & N/A & $48(92.3 \%)$ & $\mathrm{p}<0.0001$ \\
\hline
\end{tabular}

${ }^{1}$ Includes both training and test cohort

${ }^{2}$ Data are presented as mean \pm standard deviation, $\mathrm{p}$ values of numeric parameters calculated using a 2-tailed Student's t-test with unequal variance, $\mathrm{p}$ value of categorical parameters calculated using a chi-square test.

${ }^{3}$ Abbreviations: $\mathrm{M}$ - male, F - female, yr - years, B - African American, $\mathrm{W}$ - White, $\mathrm{O}$ - Other, $\mathrm{Y}$ - yes, $\mathrm{N}$ - no

${ }^{4} \mathrm{CDC}$ guideline symptom was added to the symptom questionnaire late in the study, parameter is not available for the majority of the subjects

124

${ }^{5}$ SARS-CoV-2 test was routinely administered at presentation at the hospital. The latter was for reasons other than the COVID-19 disease, e.g. accidents, pre-operation tests,

124 regular check-ups, cancer screening, injuries, chest pain

$125{ }^{6}$ Hospital and/or ICU admission for other reasons than COVID-19 disease symptoms, e.g. accidents, acute respiratory failure due to pneumonia, intentional self-harm, possible heart failure, hypertension, trauma, cancer 
medRxiv preprint doi: https://doi.org/10.1101/2021.02.05.21251173; this version posted February 8, 2021. The copyright holder for this preprint (which was not certified by peer review) is the author/funder, who has granted medRxiv a license to display the preprint in perpetuity.

It is made available under a CC-BY-ND 4.0 International license.

126

127

128

129

130

131

132

133

134

135

136

\section{Study design}

Blood was collected from study participants enrolled in the WU-350 study during their initial presentation at the hospital (d0). Further longitudinal samples were collected $3(\mathrm{~d} 3), 7$ (d7), 14 (d14), 28 (d28), and 84 (d84) days after the initial blood collection when possible. However, the collection of longitudinal samples depended on survival of the study participants as well as the participants' compliance to donate blood samples after being discharged from the hospital. A total of 704 human plasma samples from 341 patients were available for metabolomics profiling, including $324 \mathrm{~d} 0$ samples, $165 \mathrm{~d} 3$ samples, $111 \mathrm{~d} 7$ samples, 54 d14 samples, $31 \mathrm{~d} 28$ samples, and 19 d84 samples. All samples were divided into nine randomized sample batches and analyzed by liquid chromatography/mass spectrometry (LC/MS). An extract of the standard reference material SRM 1950 from NIST (National Institute of Standards and Technology, Metabolites in Frozen Human Plasma) was measured repeatedly as a quality control (QC) and blank samples were used to assess background signals. Polar and lipid metabolite fractions were extracted from each sample, and a global metabolomics profile was acquired in both positive and negative ionization modes. Processing of the data led to the putative identification of 235 polar and 472 lipid metabolites based on accurate mass and MS/MS matching. Peak areas were extracted for these 707 metabolites to form the metabolic profile of each patient.

Given that the metabolic profiles were acquired over several months, the combined data showed strong batch effects as demonstrated by the principal component analysis (PCA) in Figure S2a. To remove the variance introduced by the individual batches, but not lose the differentiating biological variance within the research (WU-350) samples, we tested several normalization approaches (Figure S2b) and selected a Combined Batch Correction (ComBat)
(Fernández-Albert et al., 2014) approach that outperformed the other common normalization 
medRxiv preprint doi: https://doi.org/10.1101/2021.02.05.21251173; this version posted February 8, 2021. The copyright holder for this preprint (which was not certified by peer review) is the author/funder, who has granted medRxiv a license to display the preprint in perpetuity.

It is made available under a CC-BY-ND 4.0 International license .

approaches tested (e.g., PQN, unit length, constant sum, quantile, etc.). After normalization, the metabolic profiles retained differences according to sample origin (WU-350, QC, blank) as shown in Figure S2c but no longer clustered based on batch (Figure S2d).

The goal of this study was to find metabolic alterations that are predictive of disease severity in SARS-CoV-2 positive individuals. We used admission to the ICU during disease progression to classify patients as having severe or non-severe disease, as has been done previously (Arunachalam et al., 2020; Petrilli et al., 2020). An ideal biomarker panel would allow an individual presenting at the hospital and receiving a positive SARS-CoV-2-PCR-test result to be screened for metabolic markers associated with severe disease progression to guide the best treatment at the earliest stage of hospitalization. Thus, we grouped the presented COV + cohort into a non-severe (COV+ non-severe) group that did not require ICU admission and a severe group $(\mathrm{COV}+$ severe $)$ that did require ICU admission. For data interpretation purposes, two study samples were excluded due to a missing SARS-CoV-2-PCR-test result, one sample due to missing clinical information, and 15 samples were excluded as they represented longitudinal samples from COV-individuals. The final patient cohort consisted of $67 \mathrm{COV}$ - cases, 145 $\mathrm{COV}+$ non-severe cases, and $129 \mathrm{COV}+$ severe cases. Unsupervised analysis of the metabolic profiles for the $324 \mathrm{~d} 0$ samples available in our patient cohort demonstrated a clear trend in principal components space that separated COV + severe, $\mathrm{COV}+$ non-severe, and COV-patients (Figure 1a). Further, several significantly varying metabolites suggested that the metabolic profiles at d0 may indeed be predictive of disease severity. Hierarchical clustering analysis (HCA) of the 54 statistically significant metabolites $(\mathrm{p}<0.05$, Welch's ANOVA) with an absolute fold change greater than two when compared to the COV-group revealed striking changes in multiple representatives of lipid classes including lysophophatidylcholines (LPCs), 
medRxiv preprint doi: https://doi.org/10.1101/2021.02.05.21251173; this version posted February 8, 2021. The copyright holder for this preprint (which was not certified by peer review) is the author/funder, who has granted medRxiv a license to display the preprint in perpetuity. It is made available under a CC-BY-ND 4.0 International license .

172 phosphatidylcholines (PCs), and triglycerides (TGs). Further, several polar metabolites known to

173 be related to COVID-19 including gluconate (Song et al., 2020) and dimethylguanosine (Migaud

174 et al., 2020) were also significantly altered (Figure 1b).

175 
a.

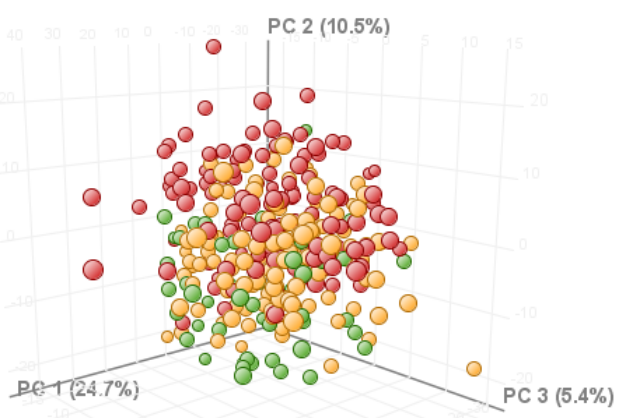

b.

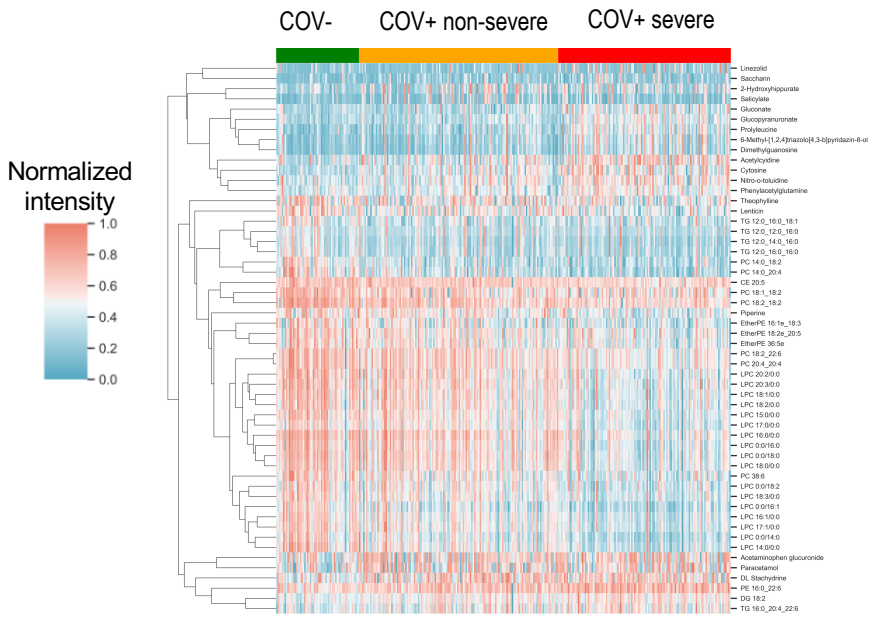

C.

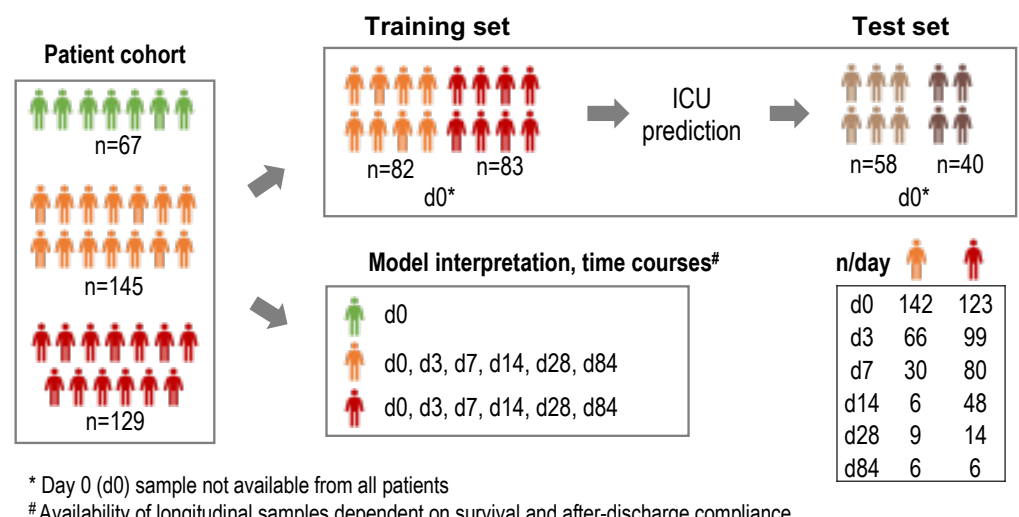

TCov-

in cov+ non-severe

i cov+ severe

Treated as unknowns

1. CoV+ non-severe

- cov+ severe

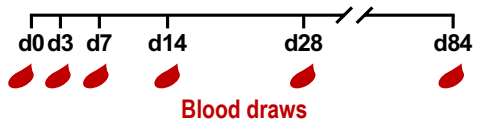

177 Figure 1. Study design. a) Principal component analysis based on all polar $(\mathrm{n}=235)$ and lipid $(\mathrm{n}=472)$ metabolites in SARS-CoV-2-negative individuals (COV-, $n=67$, green), SARS-CoV-2positive individuals with non-severe disease $(\mathrm{COV}+$ non-severe, $\mathrm{n}=142$, orange), and SARSCoV-2-positive individuals with severe disease (COV+ severe, $n=123$, red) based on the sample provided during presentation at the hospital (d0). b) Hierarchical cluster analysis of metabolic profiles of COV-, $\mathrm{COV}+$ non-severe, and $\mathrm{COV}+$ severe patients at $\mathrm{d} 0$. Represented are 54 significantly changing polar and lipid metabolites ( $\mathrm{p}<0.05$, Welch's ANOVA, BenjaminiHochberg correction). Each column is a sample and each row is a metabolite. c) Human cohort of 341 patients presenting at Barnes Jewish Hospital and Christian Hospital in St. Louis, Missouri. Nasal swab SARS-CoV-2-PCR testing resulted in 67 SARS-CoV-2-negative and 274 SARS-CoV-2-positive participants. The cohort was divided into a training cohort and a test cohort. The study design incorporated 6 blood draws for SARS-CoV-2-positive individuals on days $0(\mathrm{~d} 0), 3(\mathrm{~d} 3), 7(\mathrm{~d} 7), 14(\mathrm{~d} 14), 28(\mathrm{~d} 28)$, and $84(\mathrm{~d} 84)$ days after presentation at the hospital. 
medRxiv preprint doi: https://doi.org/10.1101/2021.02.05.21251173; this version posted February 8, 2021. The copyright holder for this preprint (which was not certified by peer review) is the author/funder, who has granted medRxiv a license to display the preprint in perpetuity.

It is made available under a CC-BY-ND 4.0 International license .

\section{Predictive model of COVID-19 disease severity}

The global trends in the $\mathrm{d} 0$ metabolic profiles visible in the PCA and HCA visualizations prompted us to develop a machine learning (ML) model of disease severity that would predict ICU admission caused by SARS-CoV-2-infection. To make this prediction, we relied on the metabolic signatures in blood plasma at the day of hospital presentation (d0). The 707 metabolites that composed the metabolic profiles served as the predictors for our ML model. To assess predictive power, we split our dataset into two distinct groups: a training set (165 patients) that we used to select, optimize, and train our ML model and a test set (98 patients) that was only used to evaluate the model's performance (Figure 1c, Table S1, Table S2). Using our training set, we evaluated the efficacy of five ML algorithms with 20 -fold cross validation and found that a linear ElasticNet (Zou and Hastie, 2005) regression model was the most effective (Figure S3a). After training the model, we applied it to the patients in the test set and assessed performance by using the area under the receiver operating characteristic curve (AUC). On the test set, we see strong predictive performance $(\mathrm{AUC}=0.72)$ that outperforms a simple model that only uses BMI and age to predict disease severity (Figure $2 \mathrm{a}$ ) and is significantly more predictive than a random model (Figure 2b, see Permutation test in Methods). As further validation, when the trained model was applied to the COV-patients (no COV-patients were in the training set), the mean scores output by the model were lower than those for the COV+ non-severe and the COV+ severe patients in the test set (Figure S3b). This indicates that the model can not only differentiate disease severity but also can distinguish $\mathrm{COV}+$ and $\mathrm{COV}$ - patients. We wish to emphasize that PCR is the gold standard to diagnose SARS-CoV-2 infection. As such, we present this result only as confirmation that our model correctly predicts disease severity and not as a diagnostic for viral infection. 
medRxiv preprint doi: https://doi.org/10.1101/2021.02.05.21251173; this version posted February 8, 2021. The copyright holder for this preprint (which was not certified by peer review) is the author/funder, who has granted medRxiv a license to display the preprint in perpetuity.

It is made available under a CC-BY-ND 4.0 International license.

We next sought to interpret which metabolites were most salient to the model's predictions. First, we computed the variable importance of the model when trained on the complete dataset, which found 93 metabolites that contributed to the model's predictions. Among this group of 93 compounds were metabolites that have been previously implicated in SARS-CoV-2 infection such as bilirubin, kynurenate, nicotinamide, creatinine, LPCs, and others (Shen et al., 2020; Song et al., 2020; Thomas et al., 2020; Wu et al., 2020a). The mean intensity of each metabolite in the $\mathrm{COV}-, \mathrm{COV}+$ non-severe, and COV+ severe groups can be seen in Figure S4. Next, we aimed to assess the robustness of the metabolites selected by the ML model. We used bootstrap resampling of our training dataset to construct confidence intervals for the variable importance of each of the 707 metabolites profiled (Mendez et al., 2020). The analysis led to the identification of 25 metabolites that significantly contributed to the model's fit. The structural identities of these metabolites were rigorously confirmed (see Methods). Strikingly, 14 of the 25 metabolites are LPCs. Using this reduced predictor set, we re-trained and re-optimized our ElasticNet model on the training set and assessed the predictive power of these 25 metabolites on our test set. Using only these 25 metabolites resulted in nearly an identical AUC to when the full set of metabolites was used $(\mathrm{AUC}=0.70)$ and still performed better than a random model or a model that used only BMI and age as predictors (Figure S5). The variable importance of these 25 metabolites when trained on the entire dataset is shown in Figure 2c. The mean intensity of the 25 metabolites in the $\mathrm{COV}-, \mathrm{COV}+$ non-severe, and $\mathrm{COV}+$ severe groups is shown in Figure $2 \mathrm{~d}$ and Figure S6. All LPCs and PCs that contributed to the model, as well as serine, presented a downward trend of signal abundance with disease severity. Conversely, the other polar metabolites, (kynurenate and 1-methyladenosine) and two phosphatidylethanolamines (PEs), exhibited an upward trend in signal intensity (Figure 2e). 
a.

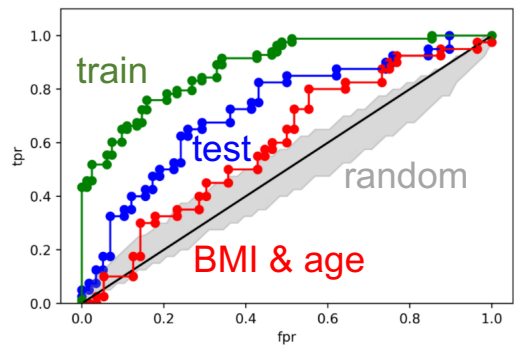

c.

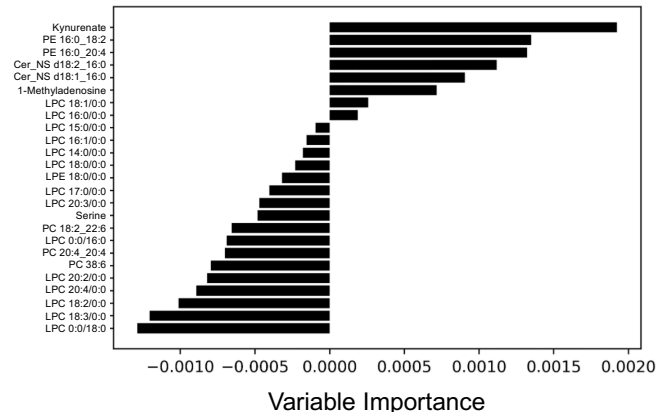

b.

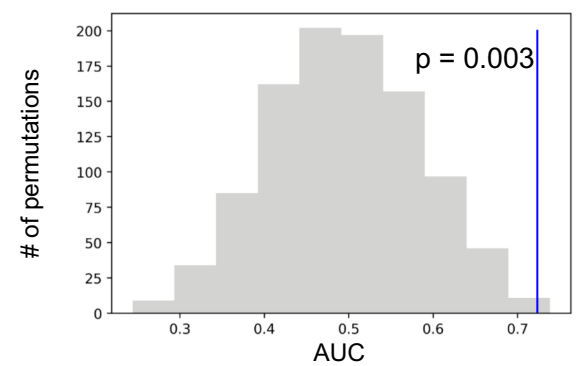

d.

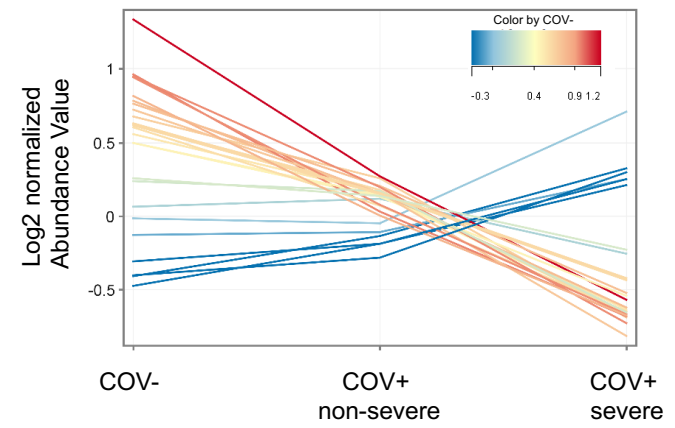

e.

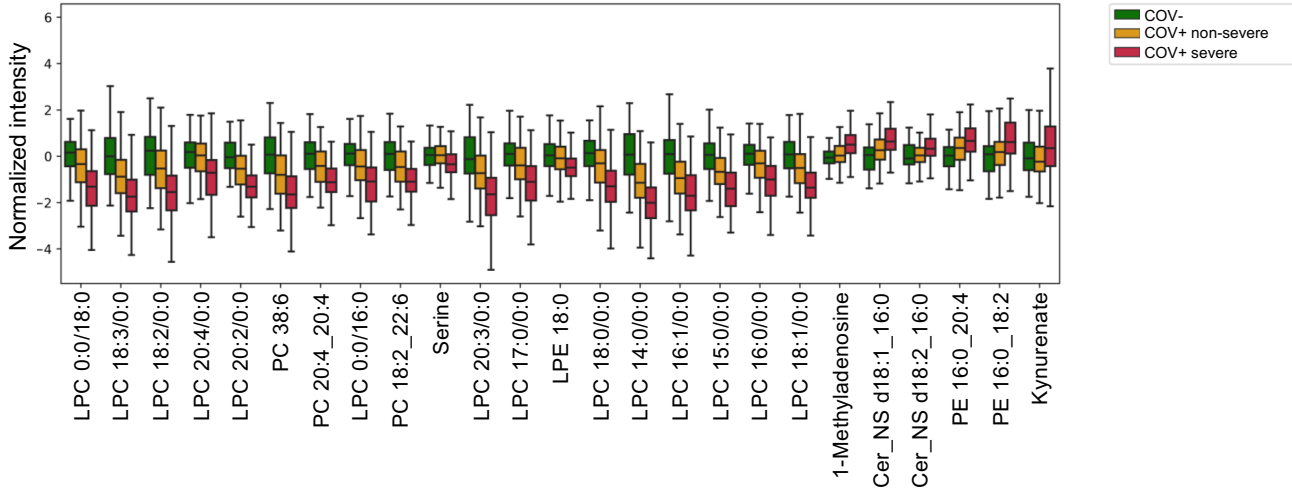

Figure 2. Predicting SARS-COV-2 severity by machine learning. a) Receiver operating characteristic (ROC) curve of prediction model on training set (green) and test set (blue). Random performance is shown in grey. ROC of BMI and age as predictors for severe COVID-19 (red) results in nearly random performance. b) Permutation test results from permuting training set labels and training the model on the permuted data. With every permutation, the area under the ROC curve (AUC) was computed. The histogram shows the distribution of these AUC values for 1000 random permutations. In blue, the model performance on the test set when trained on the non-permuted training data results in an empirical p-value of 0.003. c) Variable importance in reduced ElasticNet prediction model ( 25 metabolite predictors) for disease severity of SARS$\mathrm{CoV}$-2-infection in humans. Negative values are predictive of non-severe disease and positive values are predictive of severe disease. Variable importance is after the model is trained on the complete dataset. d) Profile plot of the normalized signal abundance of 25 prediction model metabolites grouped into COV- (control, $\mathrm{n}=67), \mathrm{COV}+$ non-severe $(\mathrm{n}=142)$, and $\mathrm{COV}+$ severe $(\mathrm{n}=123)$. e) Boxplots showing predictor metabolite intensities in the $\mathrm{COV}-, \mathrm{COV}+$ severe, and $\mathrm{COV}+$ non-severe groups. Box limits represent the quartiles of each sample group. Whiskers are drawn to $1.5 \mathrm{x}$ of the inter-quartile range. 
medRxiv preprint doi: https://doi.org/10.1101/2021.02.05.21251173; this version posted February 8, 2021. The copyright holder for this preprint (which was not certified by peer review) is the author/funder, who has granted medRxiv a license to display the preprint in perpetuity.

It is made available under a CC-BY-ND 4.0 International license .

Demographics, laboratory values, comorbidities, and COVID-19 severity.

256

257

258

260

261

262

263

264

265

266

267

268

269

270

271

272

273

After evaluating the efficacy of the ML model, we wished to deduce the relationship of our 25 robust metabolite predictors to COVID-19 disease severity. We examined whether these metabolites were reflective of an underlying condition, risk factor for severe disease, or related to the disease progression of COVID-19. We addressed the former by asking whether any of the 25 metabolites correlated with demographic factors, laboratory values, or individual patient comorbidities available for the patient cohort. A comparison of the $\mathrm{COV}+$ non-severe and severe groups identified several significantly different parameters (Table 2). The COV + severe group is significantly biased towards patients with advanced age, however, the age ranges in both groups are comparable (Figure 3a). There was no significant difference in BMI (Figure 3b), but we note that there was variability in BMI for both patient groups. $\mathrm{CO}_{2}$ levels were not significantly altered between groups (Figure 3c), with values mostly being in the normal range. In contrast, there were significantly increased levels of the inflammatory marker C-reactive protein (Figure 3d). D-dimer, absolute neutrophil count, and neutrophil \% were also increased (Figure 3e-g).

These data indicate more severe inflammation in the COV+ severe group compared to the nonsevere group and are consistent with reports from previous studies (Ahmed et al., 2020; Luo et al., 2020; Thomas et al., 2020). Neutrophil recruitment has also been shown to be dysregulated in severe COVID-19 disease (Liao et al., 2020; Park and Lee, 2020; Yang et al., 2020; Zhou et al., 2020).

Next, because specific comorbidities increase the risk of having a severe case of COVID-19 (Jain and Yuan, 2020; Petrilli et al., 2020; Smith et al., 2020), we also asked which comorbidities are enriched in the $\mathrm{COV}+$ severe group compared to the $\mathrm{COV}+$ non-severe group (Figure 3h, Table 2). The COV+ severe patients had a significantly greater proportion of 
medRxiv preprint doi: https://doi.org/10.1101/2021.02.05.21251173; this version posted February 8, 2021. The copyright holder for this preprint (which was not certified by peer review) is the author/funder, who has granted medRxiv a license to display the preprint in perpetuity.

It is made available under a CC-BY-ND 4.0 International license.

individuals suffering from acute respiratory failure, CKD, and/or diabetes. The number of individuals with cancer (or a history of cancer) and acute renal failure was not significantly different between the groups. Further, laboratory tests showed an increased proportion of individuals having hypoxia and abnormal arterial $\mathrm{pH}$ in the $\mathrm{COV}+$ severe group compared to $\mathrm{COV}+$ non-severe patients. Critically high/low $\mathrm{pH}$ values were only observed in the COV+ severe group. We note that timestamps for laboratory tests and measurements were not available for the patient cohort due to HIPPA privacy regulations. As such, these tests and measurements could have been performed at any point during an individual's hospital stay.

Considering the number of significant associations in the patient parameters between $\mathrm{COV}+$ severe and non-severe patients, we wanted to check whether any of our predictor metabolites significantly correlated with the clinical data. To that end, we computed the Pearson correlation (Benesty et al., 2009) (for continuous parameters) or the point biserial correlation (Tate, 1954) (for binary parameters) between each predictor metabolite and patient parameter (Figure 3i). The analysis did not reveal any strong correlations between patient parameters and our predictor metabolites. The only significant but moderate correlation with age was with 1-methyladenosine $(\mathrm{r}=0.4)$, which was also correlated weakly with $\mathrm{CKD}(\mathrm{r}=0.37)$ and neutrophil percentage $(r=0.39)$. Significant but weak correlations $(r=0.37)$ were observed for kynurenate and CKD, which has been described previously (Gagnebin et al., 2020). Further, C-reactive protein and neutrophil percentages have a moderate positive correlation with the ceramide (Cer) Cer-NS d18:1_16:0 $(\mathrm{r}=0.47)$ and PE 16:0_18:2 $(\mathrm{r}=0.43)$. Both the C-reactive protein values and the neutrophil percentages are weakly to moderately negatively correlated with most of the LPCs and serine levels $(\mathrm{r}=[-0.4,-0.31])$, indicating that the reduction of LPCs and serine is concomitant with the immune response to SARS-CoV-2 infection (Mudd et al., 2020). Notably, 
301 the majority of our predictor metabolites had only weak or insignificant correlations with the 302 comorbidities or patient parameters.

303 We next sought to assess the predictive power of our ML model (when trained on the training 304 set) relative to the predictive power of the patient comorbidities. Thus, for each patient

305 comorbidity we computed the AUC when predicting disease severity based on the comorbidity

306 status for each patient in the test set (Figure 3j). For all evaluated comorbidities, the model

307 achieves a higher AUC. Taken together, these results suggest that our predictor metabolites are 308 indeed relevant to the pathogenesis of SARS-CoV-2 infection and not merely markers of other 309 risk factors. 
medRxiv preprint doi: https://doi.org/10.1101/2021.02.05.21251173; this version posted February 8, 2021. The copyright holder for this preprint (which was not certified by peer review) is the author/funder, who has granted medRxiv a license to display the preprint in perpetuity.

It is made available under a CC-BY-ND 4.0 International license .

312 Table 2. Demographics, Comorbidities and Lab values of SARS-CoV-2-infected individuals

313 with d0 sample available ${ }^{1,2,3}$.

\begin{tabular}{|c|c|c|c|}
\hline Parameter & COV+ non-severe & COV+ severe & p-value \\
\hline $\mathrm{n}$ & 142 & 123 & \\
\hline Gender $(\mathrm{M} / \mathrm{F})$ & $75 / 67$ & $77 / 46$ & $\mathrm{p}=0.1082$ \\
\hline Age (yr) & $55 \pm 17$ & $66 \pm 15$ & $\mathrm{p}<0.0001$ \\
\hline Age range (yr) & $19.2-92.7$ & $19.3-90.8$ & \\
\hline Race (African American/White/other) & $109 / 30 / 3$ & $88 / 35 / 0$ & $\mathrm{p}=0.1987$ \\
\hline BMI & $32 \pm 9$ & $30 \pm 10$ & $\mathrm{p}=0.1107$ \\
\hline Current smoker & 24 & 11 & $\mathrm{p}=0.0564$ \\
\hline Deceased & 3 & 47 & $\mathrm{p}<0.0001$ \\
\hline Deceased due to COVID-19 & 2 & 44 & $\mathrm{p}<0.0001$ \\
\hline \multicolumn{4}{|l|}{ Comorbidities } \\
\hline Acute respiratory failure & 27 & 68 & $\mathrm{p}<0.0001$ \\
\hline Chronic kidney disease & 40 & 49 & $\mathrm{p}=0.0449$ \\
\hline Acute renal failure & 9 & 12 & $\mathrm{p}=0.3043$ \\
\hline Diabetes & 59 & 68 & $\mathrm{p}=0.0256$ \\
\hline Cancer (history/current) & $5(3 / 2)$ & $8(5 / 4)$ & $\mathrm{p}=0.2622$ \\
\hline \multicolumn{4}{|l|}{ Laboratory Results } \\
\hline Hypoxia & 34 & 76 & $\mathrm{p}<0.0001$ \\
\hline Low arterial $\mathrm{pH}$ & 4 & 62 & $\mathrm{p}<0.0001$ \\
\hline High arterial $\mathrm{pH}$ & 4 & 61 & $\mathrm{p}<0.0001$ \\
\hline Low/High arterial $\mathrm{pH}$ & 6 & 80 & $\mathrm{p}<0.0001$ \\
\hline Extreme $\mathrm{pH}$ & 0 & 33 & $\mathrm{p}<0.0001$ \\
\hline C-reactive protein $(\mathrm{mg} / \mathrm{L})$ & $67.8 \pm 65.45(\mathrm{n}=89)$ & $154.6 \pm 110.9(\mathrm{n}=101)$ & $\mathrm{p}<0.0001$ \\
\hline D-dimer (ng/mL FEU) & $2614 \pm 6839(\mathrm{n}=91)$ & $5895 \pm 10682(\mathrm{n}=103)$ & $\mathrm{p}=0.108$ \\
\hline Neutrophil absolute (K/cumm) & $4.806 \pm 2.635(n=135)$ & $7.644 \pm 5.602(n=117)$ & $\mathrm{p}<0.0001$ \\
\hline Neutrophil (\%) & $66.95 \pm 12.03(n=135)$ & $78.01 \pm 12.10(n=117)$ & $\mathrm{p}<0.0001$ \\
\hline $\mathrm{CO}_{2}$, Total $(\mathrm{mmol} / \mathrm{L})$ & $24.86 \pm 3.78(\mathrm{n}=138)$ & $24.10 \pm 4.17(\mathrm{n}=122)$ & $\mathrm{p}=0.1287$ \\
\hline
\end{tabular}

314

315

Includes both training and test cohort

${ }^{2}$ Data are presented as mean \pm standard deviation, $\mathrm{p}$ values of numeric parameters calculated using a 2-tailed Student's t-test with unequal variance, $\mathrm{p}$ value of categorical parameters calculated using a chi-square test.

316

Abbreviations: M - male, F - female, yr - years, B - African American, W - White, O - Other, Y - yes, N - no 

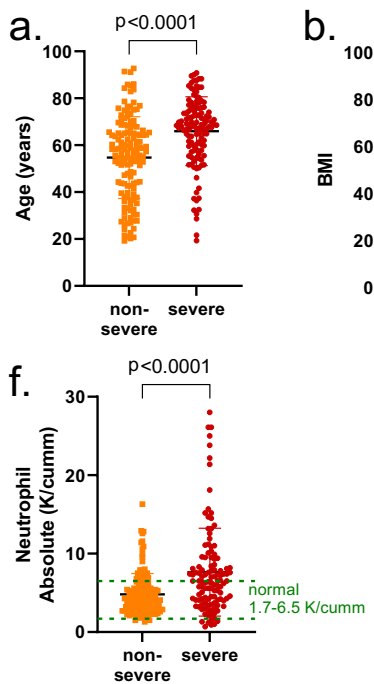

g.

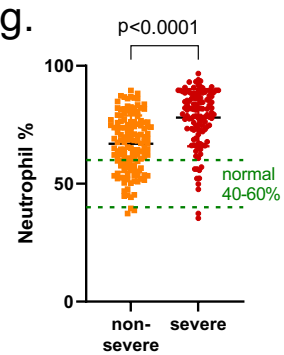

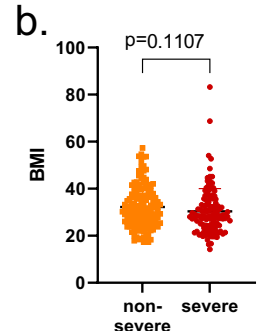

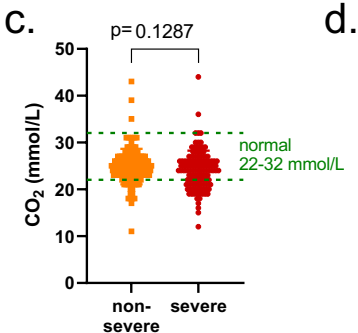

h.

$$
\text { d. }
$$
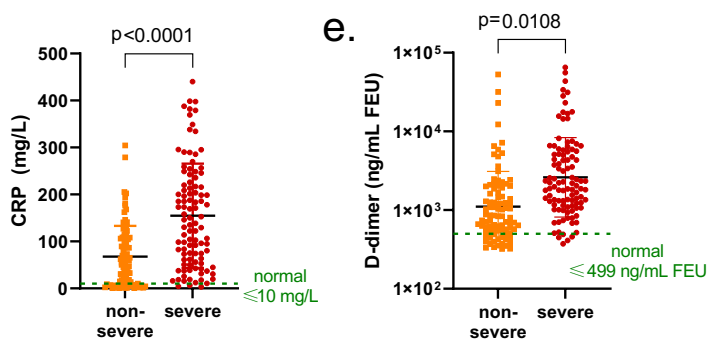

i.

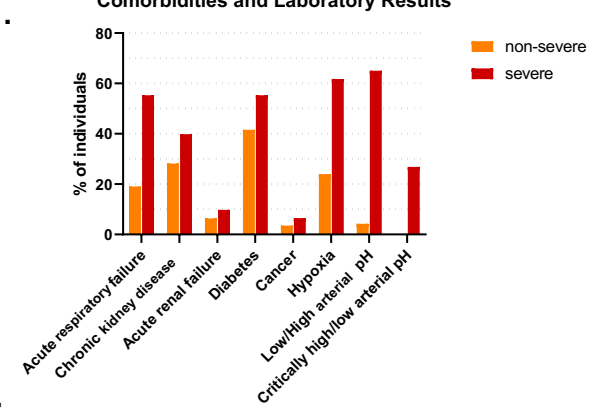

j.

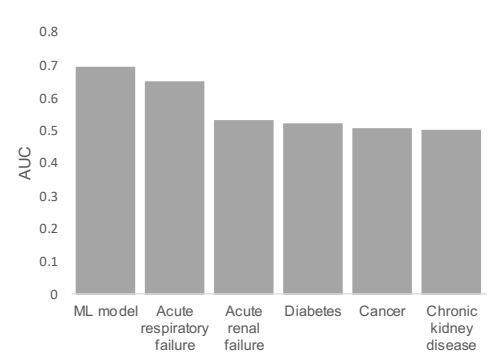

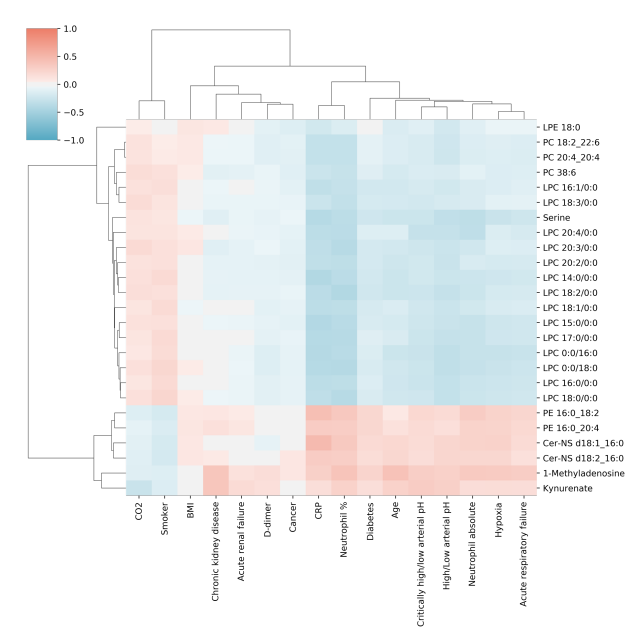

Figure 3. $\mathrm{COV}+$ patient parameters. Demographics, comorbidities, and laboratory values of SARS-CoV-2-positive cases grouped by disease severity (non-severe, severe) for age (a), BMI (b), $\mathrm{CO}_{2}$ (c), C-reactive protein (d), D-dimer (e), absolute neutrophil levels (f), and neutrophil percentage (g). Statistical significance was assessed with a 2-tailed Student's t-test with unequal variance for data shown in (a-g). h) proportion of COV+ severe and non-severe patients with particular comorbidities and laboratory test results. i) Pearson correlation of listed demographic/laboratory results/comorbidities with abundances of the predictor metabolites. $\mathrm{j}$ ) Area under the ROC curve (AUC) values for patient comorbidities and the ML model when predicting disease severity on the test set patients. 
medRxiv preprint doi: https://doi.org/10.1101/2021.02.05.21251173; this version posted February 8, 2021. The copyright holder for this preprint (which was not certified by peer review) is the author/funder, who has granted medRxiv a license to display the preprint in perpetuity.

It is made available under a CC-BY-ND 4.0 International license.

\section{Longitudinal progression of predictor metabolites}

To give further confidence that our predictor metabolites are associated with COVID-19

pathogenesis, we next aimed to determine how the levels of these metabolites changed over the course of disease progression. First, we considered the portion of the COV+ severe cohort that survived SARS-CoV-2-infection. We sought to determine the temporal behavior of their metabolic profiles as patients reach peak disease severity and after recovery. Accordingly, we compared the longitudinal metabolite abundances from individuals who had severe disease but survived and were discharged from the hospital. We compared their initial d0 plasma sample with the sample taken closest to the day of ICU admission and the last sample provided by the patient at or after hospital discharge. For several LPCs and one PC, a V-shaped trend was observed (Figure 4a). After the initial sample (d0), the level of these metabolites dropped further as the disease worsened but then began to restore during recovery. The reverse trend was observed for Cer-NS d18:1_16:0. Its levels significantly increased until the patients were admitted to the ICU. However, the levels sharply dropped to below the initial d0 levels in the final sample obtained.

These pronounced longitudinal trends in surviving $\mathrm{COV}+$ severe patients raised the question of how the trajectory of disease progression (as marked by our predictor metabolites) differed among $\mathrm{COV}+$ non-severe patients, surviving $\mathrm{COV}+$ severe patients, and deceased $\mathrm{COV}+$ severe patients. Further, we wished to compare the end points in these groups to the COV- d0 patients. We constructed representative metabolite profiles for the groups by using the 25 predictor metabolites at each of the study time points (d0, d3, d7, d14, d28, and d84) and performed a principal component analysis that enabled the trajectory of each group to be drawn out in two dimensions (Figure 4b). Strikingly, the analysis revealed three distinct trajectories with starting 
352 points that trended with disease severity. The groups then followed a common trajectory through

$353 \mathrm{~d} 14$, after which deceased and surviving COV+ severe patients diverge, and COV+ non-severe

354 patients rapidly progress to the end of the trajectory that is constant for $\mathrm{d} 28$ and $\mathrm{d} 84$. For both

355 surviving $\mathrm{COV}+$ severe patients and $\mathrm{COV}+$ non-severe patients, the endpoint is close to that of

356 the $\mathrm{d} 0 \mathrm{COV}$ - patients. However, $\mathrm{COV}+$ non-severe patients reach this point faster. Conversely,

357 for deceased COV+ patients, after d14, the metabolic profile moves further away from the COV-

358 profile staying relatively constant in principal component one (explaining $84 \%$ of the variance)

359 but increasing away from COV- in principal component two (explaining $8 \%$ of variance). No

$360 \mathrm{~d} 84$ samples were available for deceased COV+ severe patients. We next examined the

361 individual metabolite levels within the four groups at each time point. The deceased COV+

362 severe patients show the same direction of dysregulation across the predictor metabolites as the

363 surviving COV+ severe patients, but the magnitude of the perturbation is increased. Unlike the

364 other groups, these deceased patients show no recovery throughout the disease progression

365 (Figure S7). 
a.

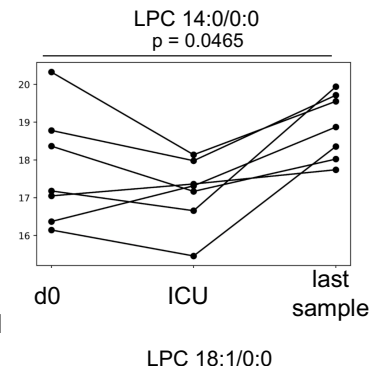

intensity

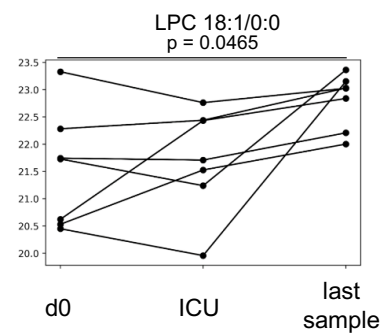

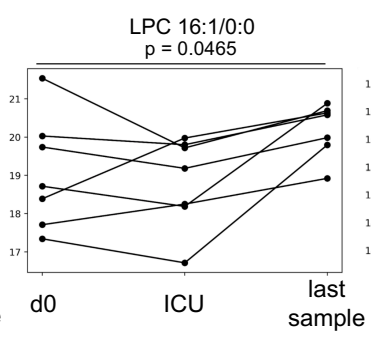

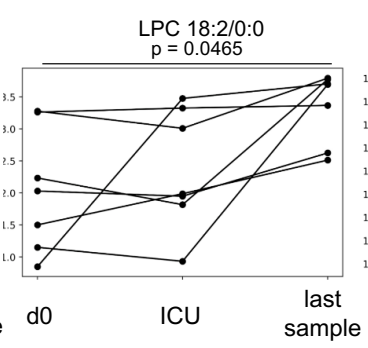

b.

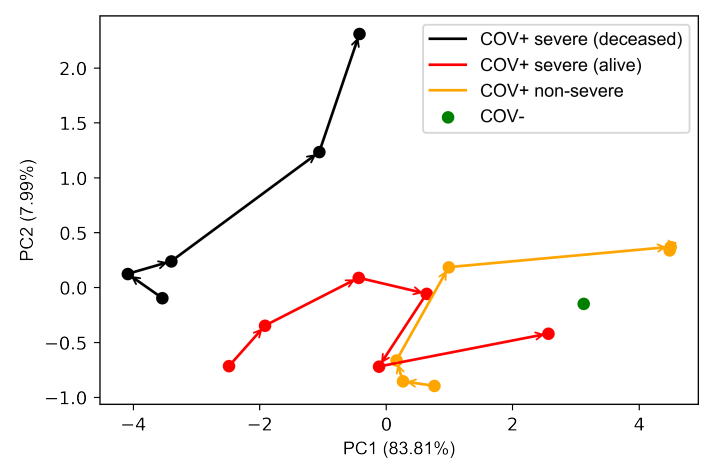

Figure 4. Course of disease progression. a) Prediction model metabolites that significantly vary in intensity as a function of disease progression for SARS-CoV-2 positive patients surviving severe disease (COV+ severe). $\mathrm{d} 0$ denotes the first sample after hospital admission, ICU denotes the sample collected closest to ICU admission, and the last sample is the final sample collected for the patient. Only patients where these time points were distinct samples were used. Statistical significance was assessed by using a repeated measures one-way ANOVA with BenjaminiHochberg correction. b) Principal components analysis showing the trajectory of the mean metabolic profile of the 25 predictor metabolites in $\mathrm{COV}+$ non-severe patients (orange), surviving $\mathrm{COV}+$ severe patients (red), and deceased $\mathrm{COV}+$ severe patients (black). No d84 samples were available for deceased $\mathrm{COV}+$ severe patients. The last two points for $\mathrm{COV}+$ nonsevere patients overlap. In green, the mean d0 metabolic profile of $\mathrm{COV}$ - patients is shown. The surviving $\mathrm{COV}+$ patient profiles approach the $\mathrm{d} 0 \mathrm{COV}$ - profile by $\mathrm{d} 84$. 
Next, we sought to compare the longitudinal progression of the predictor metabolites between

383 the surviving $\mathrm{COV}+$ patients. In the COV+ severe group, the LPC levels increased over the

384 course of 84 days to levels that are comparable to the $\mathrm{COV}$ - group ( $\mathrm{FC}=1$, Figure 5a). In the

$385 \mathrm{COV}+$ non-severe group, the LPC levels recovered faster, and, at day 28, an overcompensation

386 occurred resulting in higher LPC levels than in the COV-group ( $\mathrm{FC}=1$, Figure 5b). In total, 22

387 out of the 25 predictor metabolites showed a significant change $(p<0.05$, Welch's ANOVA)

388 across the longitudinal timepoints in the COV+ severe group (Figure 5c). All 14 LPCs

389 significantly increased over time, as well as lysophosphatidylethanolamine (LPE) 18:0, PC 38:6,

390 PC 20:4_20:4, and PC 18:2_22:6. Kynurenate, Cer-NS d18:1_16:0, Cer-NS d18:2_16:0, and PE

391 16:0_20:4 showed a decreasing trend after initially being increased compared to the d0 sample of

392 the COV-group. Due to lower sample numbers, the COV+ non-severe group had only 11

393 metabolites that showed a significant trend $(\mathrm{p}<0.05$, Welch's ANOVA, Figure 5d). These 11

394 metabolites are composed of 8 LPCs, Cer-NS d18:1_16:0, PC 38:6, and LPE 18:0. 
medRxiv preprint doi: https://doi.org/10.1101/2021.02.05.21251173; this version posted February 8, 2021. The copyright holder for this preprint (which was not certified by peer review) is the author/funder, who has granted medRxiv a license to display the preprint in perpetuity.

It is made available under a CC-BY-ND 4.0 International license .

a.

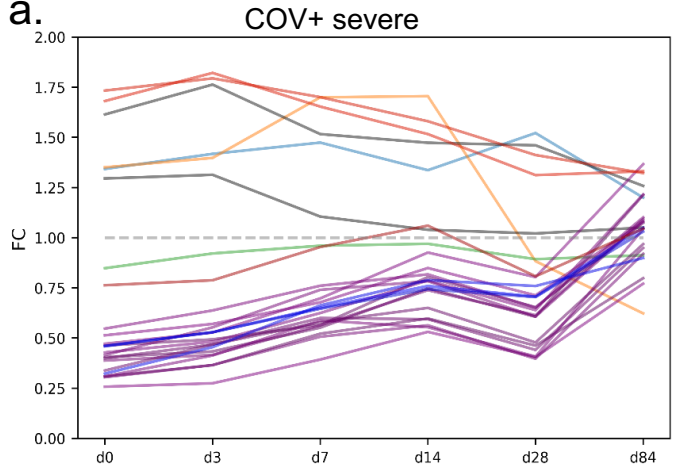

C.

$\mathrm{COV}+$

severe

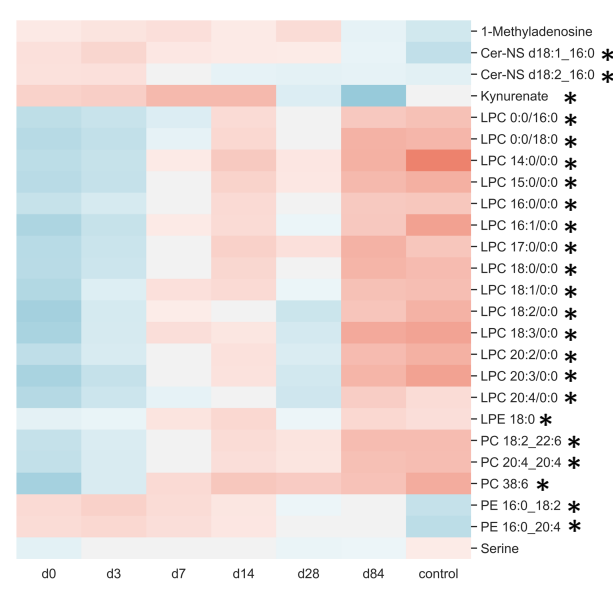

b.

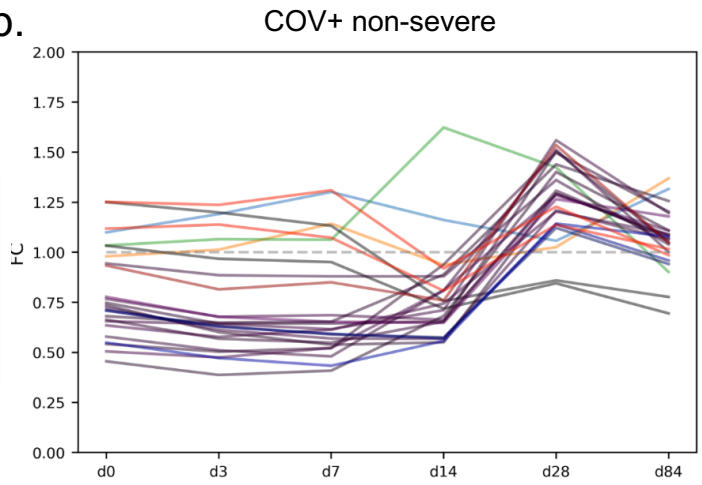

d.

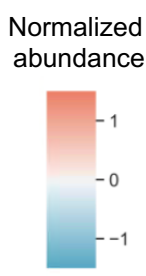

Figure 5. Longitudinal trends in $\mathrm{COV}+$ patients. Changes in plasma levels of the 25 predictor metabolites over the course of the SARS-CoV-2-infection (d0 through d84). a) Profile plot of the mean predictor metabolite intensities relative to d0 COV- samples ( $\mathrm{n}=67$, grey) in SARS-CoV-2positive individuals with severe COVID-19-disease $(n=123, \mathrm{COV}+$ severe) who survived and were discharged from the hospital. b) Profile plot of the mean predictor metabolite intensities in SARS-CoV-2-positive individuals with non-severe disease $(n=142, \mathrm{COV}+$ non-severe). $\mathrm{c}-\mathrm{d})$ Heatmaps showing relative mean intensity of predictor metabolites in longitudinal profiles of $\mathrm{COV}+$ severe patients (c) or COV+ non-severe patients (d). The mean COV- d0 profiles are included as the control for reference. $*$ indicates a $p$-value $<0.05$. Statistical significance was assessed using a one-way Welch's ANOVA with Benjamini-Hochberg correction. 
medRxiv preprint doi: https://doi.org/10.1101/2021.02.05.21251173; this version posted February 8, 2021. The copyright holder for this preprint (which was not certified by peer review) is the author/funder, who has granted medRxiv a license to display the preprint in perpetuity.

It is made available under a CC-BY-ND 4.0 International license .

\section{Syrian Hamster Model Confirms Metabolite Changes in COVID-19 Disease}

Lastly, we aimed to validate that the trends observed for the predictor metabolites in the patient samples also appeared in an established animal model of SARS-CoV-2 infection (Chan et al., 2020; Imai et al., 2020). Syrian hamsters have been found to be susceptible to SARS-CoV-2 infection, with the virus mainly replicating in the upper and lower respiratory tract of intranasally challenged animals for approximately six days post-infection. The animals also show signs of disease characterized by body weight lost and pathological lung inflammation. We obtained plasma samples from golden Syrian hamsters that were intranasally inoculated with SARS-CoV2, influenza virus, or nasally treated with saline solution as a mock infection. Relative to the body weights of the mock hamsters, hamsters infected with SARS-CoV-2 experienced significant bodyweight loss (approximately 15\%) while hamsters infected with influenza virus did not lose body weight, which is consistent with a previous report (Iwatsuki-Horimoto et al., 2018). After 2, 4, 6, and 14 days (d2, d4, d6, and d14) post-infection, plasma was harvested from the SARS-CoV-2 and influenza virus-infected hamsters (Figure 6a). For the mock group, plasma was harvested on days 4 and 14 relative to the infection timeline. All plasma samples were subjected to the same LC/MS workflow as described above. Of our 25 metabolite predictors, all but PC 20:4_20:4 was detected in the hamster plasma. We compared samples from the three groups (SARS-CoV-2, influenza, and mock) harvested on d4, when the disease was fully established (Chan et al., 2020; Imai et al., 2020). Figure 6b summarizes the significantly changing predictor metabolites ( $\mathrm{p}<0.05$, Welch's ANOVA) across the three groups. The LPCs showed the same trend as what was observed in the human samples (i.e., a significant depression when compared to the control group). For all significantly varying metabolites, with the exception of PE 16:2_20:4, infection with the influenza virus showed a similar trend of 
431 dysregulation away from control samples but a very different magnitude compared to a SARS-

432 CoV-2 infection. This is consistent with lower rates of body weight loss in influenza virus-

433 infected hamsters as compared to those infected with SARS-CoV-2. Finally, we wanted to

434 determine whether the predictor metabolites in hamsters showed a similar recovery trend over 14

435 days of infection to what we observed in human patients over a period of 84 days of infection.

436 Indeed, there is a similar trend in the SARS-CoV-2 infected hamsters (Figure 6c) as in the

437 human COV+ samples when compared to the $\mathrm{d} 4$ control (mock) samples. LPC levels dropped

438 significantly on $\mathrm{d} 4$ and slowly recovered towards the control levels on d14. By comparison, in

439 the influenza virus-infected group, levels of most metabolites approached that of the control

440 group more rapidly (Figure 6d). 
a.

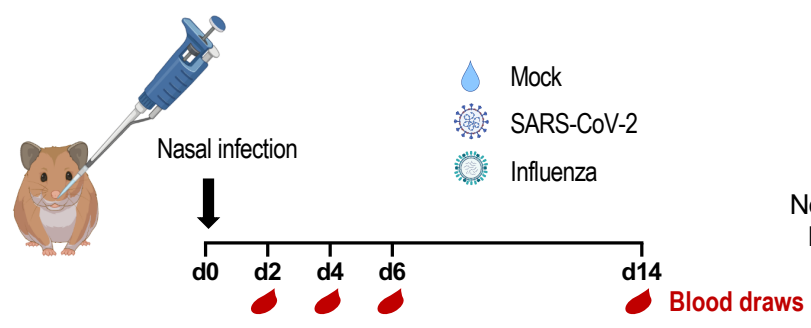

SARS-CoV-2

C.

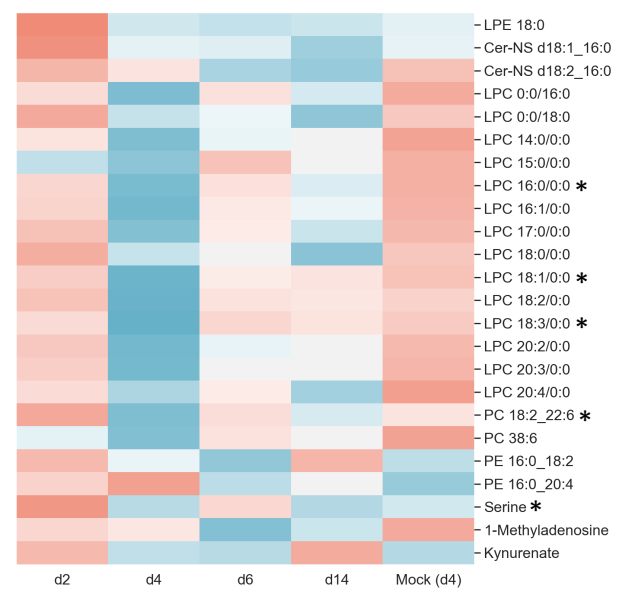

b.

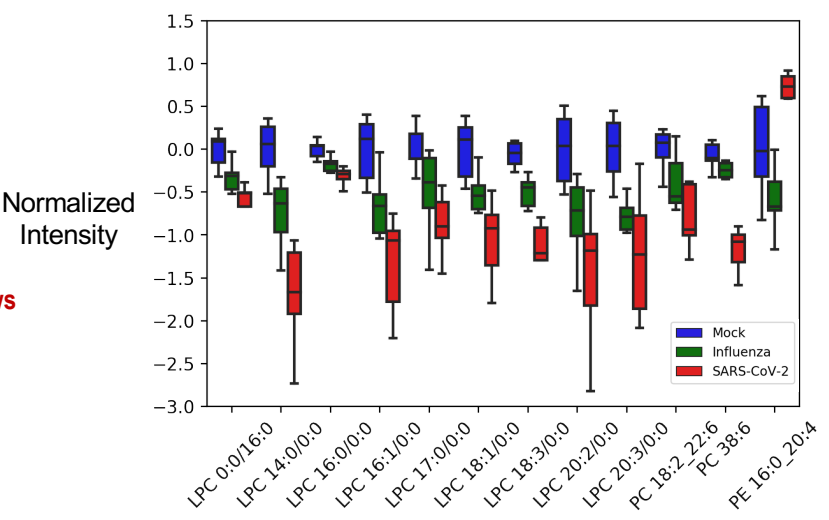

Influenza

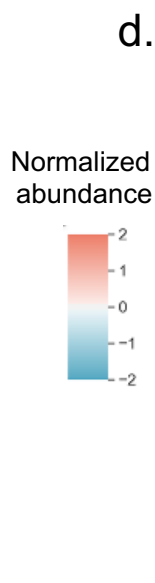

d.

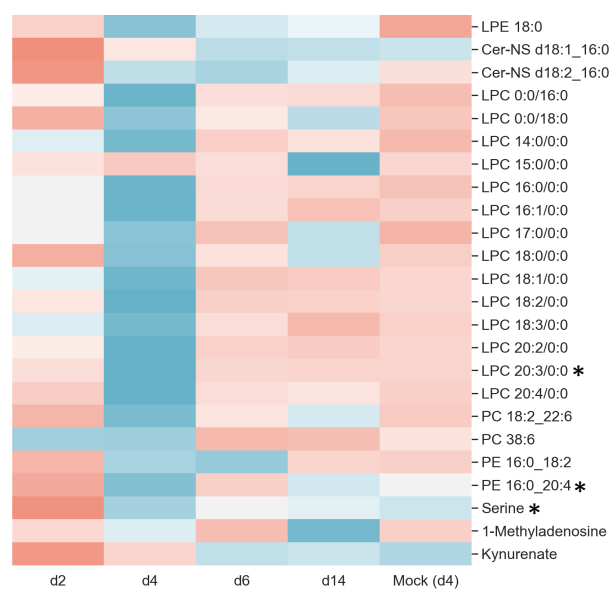

Figure 6. Syrian Hamster model confirms SARS-CoV-2-dependent metabolite changes. a) Experimental design of Syrian hamster model. Hamsters ( $\mathrm{n}=3-6$ per group) were infected through intranasal installation of SARS-CoV-2 (1e5 PFU), influenza virus (1e5 PFU), or nasally treated with a saline solution (mock) on day $0(\mathrm{~d} 0)$. Blood was drawn 2, 4, 6, and 14 days (d2, $\mathrm{d} 4, \mathrm{~d} 6, \mathrm{~d} 14$ ) post-infection. Nasal washes were performed on day 1, 3, 5, 7, and 9 post-infection. b) Comparing metabolite intensity between hamsters infected with influenza $(n=6)$, SARS-CoV$2(\mathrm{n}=5)$, and mock $(\mathrm{n}=6)$ on $\mathrm{d} 4$ shows many of the predictor metabolites are significantly altered in the hamster model ( $<<0.05$, Welch's ANOVA). Box limits represent the quartiles of each sample group. Whiskers are drawn to $1.5 \mathrm{x}$ of the inter-quartile range. $\mathrm{c}-\mathrm{d})$ Metabolite changes during disease progression in SARS-CoV-2 (c) and influenza (d) infected animals show a faster recovery for influenza infected animals. All groups are $n=6$ with the exception of SARS-CoV-2 hamsters at $\mathrm{d} 2(\mathrm{n}=3)$ and $\mathrm{d} 4(\mathrm{n}=5) . *$ indicates a $\mathrm{p}$-value less than 0.05 . Statistical significance was assessed with a 2-tailed Student's t-test with unequal variance between $\mathrm{d} 2$ and $\mathrm{d} 4$ samples. All values were corrected with the Benjamini-Hochberg procedure. 
medRxiv preprint doi: https://doi.org/10.1101/2021.02.05.21251173; this version posted February 8, 2021. The copyright holder for this preprint (which was not certified by peer review) is the author/funder, who has granted medRxiv a license to display the preprint in perpetuity.

It is made available under a CC-BY-ND 4.0 International license .

\section{Discussion}

The current study sought to predict COVID-19 disease severity based on the metabolic profiles of human plasma samples obtained early in the disease course, prior to the onset of critical illness. We applied untargeted metabolomics to profile a patient cohort of 341 individuals, which amounted to over 700 study samples in addition to QC and method blanks. In these samples, we putatively identified 235 polar metabolites and 472 lipid metabolite species. Using these metabolites, we applied machine learning techniques to build a predictive model that can accurately classify a patient's disease severity from their day 0 metabolic profile obtained at the time of initial hospital admission. This differentiating power may be critical in the coming months as SARS-CoV-2 infections continue to rise and hospital resources for treating severe disease become increasingly more limited. Due to insufficient availability, for example, casirivimab and imdevimab are currently only indicated for the treatment of patients who are at high risk of progressing to severe COVID-19 (2020a). At this time, risk assessment is based on BMI and age (FDA, 2020). Even though we see a significant difference between the age of the non-severe and severe disease group $(\mathrm{p}<0.0001)$, the results of this study show that risk assessment based on our 25 predictor metabolites is more reliable than age and BMI and therefore provides a better metric for resource allocation.

Our linear ElasticNet model is relatively simple compared to other popular ML models, including artificial neural networks, support vector machines (SVM), or ensemble based approaches such as random forest (RF) that have been applied to metabolomics datasets previously (Mendez et al., 2019). However, linear models can be easily interpreted and provide robust performance (Mendez et al., 2019; Zou and Hastie, 2005). Indeed, a previous study (Overmyer et al., 2020) successfully used an ElasticNet model to predict disease severity from a 
medRxiv preprint doi: https://doi.org/10.1101/2021.02.05.21251173; this version posted February 8, 2021. The copyright holder for this preprint (which was not certified by peer review) is the author/funder, who has granted medRxiv a license to display the preprint in perpetuity.

It is made available under a CC-BY-ND 4.0 International license.

481

482

483

484

485

486

487

488

489

490

491

492

493

494

495

496

497

498

499

500

501

502

503

multi-omic dataset. A limitation of the ElasticNet approach is that it is a linear model and most biological systems are innately non-linear. Other studies have used non-linear ML models such as RF to predict disease severity from metabolomics, lipidomics, and/or proteomics profiles (Fraser et al., 2020; Shen et al., 2020). Although these studies found higher AUC scores than that of our model, they used considerably smaller patient cohorts than what our model was trained and evaluated on. When we tested non-linear models (RF and SVM), we found worse crossvalidated performance than ElasticNet (see Figure S3a). Another challenge we faced in building a model of disease severity is that the size of our study required normalizing metabolic profiles acquired in multiple batches. We demonstrated that ComBat normalization was able to remove the variance resulting from these batch effects. In removing this variance, however, true biological variation was undoubtedly removed. Despite these limitations, our model still accurately predicted patient disease severity.

Interpretation of our model led us to identify 25 robust predictor metabolites whose identities were rigorously confirmed. Using this reduced predictor set, we were able to retrain our model and found similarly strong predictive ability. Our large sample size that included longitudinal measurements of patient plasma and collection of patient metadata (laboratory values, comorbidities, and demographics) allowed us to uniquely validate the relationship of these 25 metabolites to COVID-19 disease severity. Further, we confirmed the relevance of these metabolites to the pathology associated with SARS-CoV-2 infection by using an established animal model of COVID-19. It is important to point out that the 25 metabolites we discovered to predict disease severity can be readily measured by using targeted methods on triple quadrupole mass spectrometers that are widely available in most clinical laboratories. Thus, the test we present here to assess the risk of a severe case of COVID-19 does not require intensive 
medRxiv preprint doi: https://doi.org/10.1101/2021.02.05.21251173; this version posted February 8, 2021. The copyright holder for this preprint (which was not certified by peer review) is the author/funder, who has granted medRxiv a license to display the preprint in perpetuity. It is made available under a CC-BY-ND 4.0 International license.

504 computation or untargeted metabolomics, making it immediately applicable to most hospitals in 505 the United States.

506 


\section{Methods}

Study design

Over the period of March to August of 2020, blood specimens of 341 individuals who presented at Barnes Jewish Hospital or Christian Hospital located in Saint Louis, Missouri, USA were collected. Inclusion criteria were a physician-ordered SARS-CoV-2-PCR test with a positive or negative outcome, availability of gender and age information, and an age greater than 18. Informed consent was obtained from all study participants. Samples were collected at the time of enrollment (d0), which was during or immediately following presentation at the hospital, and $3,7,14,28$, or 84 days post hospital presentation. Clinically relevant medical information (e.g., patient-reported symptoms, date of symptom-onset, age, race, and BMI) was collected at the time of enrollment from the subject, their legally authorized representative, or the medical record.

\section{Metabolomics sample preparation}

Participant plasma, which had been stored at $-80{ }^{\circ} \mathrm{C}$ upon collection, was thawed on ice. A $50 \mu \mathrm{L}$ aliquot was transferred onto the solid-phase-extraction (SPE)-system CAPTIVA-EMR Lipid 96-wellplate (Agilent Technologies) before addition of $250 \mu \mathrm{L}$ of acetonitrile containing $1 \%$ formic acid (v/v) and $10 \mu \mathrm{M}$ internal standard (consisting of uniformly ${ }^{13} \mathrm{C}$ and ${ }^{15} \mathrm{~N}$ labeled amino acids from Cambridge Isotope Laboratories, Inc). The samples were mixed for $1 \mathrm{~min}$ at $360 \mathrm{rpm}$ on an orbital shaker at room temperature prior to a $10 \mathrm{~min}$ incubation period at $4{ }^{\circ} \mathrm{C}$. Afterwards, $200 \mu \mathrm{L} 80 \%$ acetonitrile in water $(\mathrm{v} / \mathrm{v})$ were added to the samples. The samples were mixed on an orbital shaker $(360 \mathrm{rpm})$ for an additional $10 \mathrm{~min}$ at room temperature. The samples were then eluted into a 96-deepwell collection plate by centrifugation $\left(10 \mathrm{~min}, 57 \times \mathrm{g}, 4^{\circ} \mathrm{C}\right.$ 
medRxiv preprint doi: https://doi.org/10.1101/2021.02.05.21251173; this version posted February 8, 2021. The copyright holder for this preprint (which was not certified by peer review) is the author/funder, who has granted medRxiv a license to display the preprint in perpetuity.

It is made available under a CC-BY-ND 4.0 International license .

529 followed by $2 \mathrm{~min}, 1000 \mathrm{x} g, 4^{\circ} \mathrm{C}$ ). Polar eluates were stored at $-80{ }^{\circ} \mathrm{C}$ until the day of LC/MS

530 analysis.

531

The SPE-plates were then washed twice with $500 \mu \mathrm{L} 80 \%$ acetonitrile in water (v/v). Lipids

still bound to the SPE-material were then released into a second elution plate, in two elution

533 steps applying 2x $500 \mu \mathrm{L}$ 1:1 methyl tert-butyl ether:methanol (v/v) onto the SPE cartridge and

534 centrifuging for $2 \mathrm{~min}$ at $1000 \mathrm{~g}$ and $4{ }^{\circ} \mathrm{C}$. The combined eluates were dried under a stream of

535 nitrogen (Biotage SPE Dry Evaporation System) at room temperature and reconstituted with 100

$536 \mu \mathrm{L}$ 1:1 2-propanol:methanol (v/v) prior to LC/MS analysis.

Hamster plasma samples were diluted 1:4 with methanol (v/v), vortexed for 30 seconds and incubated at $-20^{\circ} \mathrm{C}$ for 2 hours. Samples were centrifuged for 10 minutes at $13,500 \times g$ at $4^{\circ} \mathrm{C}$ and supernatant was transferred to a new centrifuge tube, concentrated, and stored at $-80^{\circ} \mathrm{C}$ until reconstitution as described above.

$548{ }^{\circ} \mathrm{C}$ and the flow rate was set to $250 \mu \mathrm{L} \cdot \mathrm{min}^{-1}$. The mobile phases consisted of A: $95 \%$ water, $5 \%$ acetonitrile, $20 \mathrm{mM}$ ammonium bicarbonate, $0.1 \%$ ammonium hydroxide solution (25\%

550 ammonia in water), $2.5 \mu \mathrm{M}$ medronic acid, and B: 95\% acetonitrile, $5 \%$ water, $2.5 \mu \mathrm{M}$ medronic 
medRxiv preprint doi: https://doi.org/10.1101/2021.02.05.21251173; this version posted February 8, 2021. The copyright holder for this preprint (which was not certified by peer review) is the author/funder, who has granted medRxiv a license to display the preprint in perpetuity.

It is made available under a CC-BY-ND 4.0 International license .

551 acid. The following linear gradient was applied: 0 to $1 \mathrm{~min}, 90 \% \mathrm{~B} ; 12 \mathrm{~min}, 35 \% \mathrm{~B} ; 12.5$ to 14.5

$552 \min , 25 \% \mathrm{~B} ; 15 \mathrm{~min}, 90 \% \mathrm{~B}$ followed by a re-equilibration phase of $4 \mathrm{~min}$ at $400 \mu \mathrm{L} \cdot \mathrm{min}^{-1}$ and 2

$553 \mathrm{~min}$ at $250 \mu \mathrm{L} \cdot \mathrm{min}^{-1}$. Metabolites were detected in positive and negative ion mode with the

554 following source parameters: gas temperature $200^{\circ} \mathrm{C}$, drying gas flow $10 \mathrm{~L} \cdot \mathrm{min}^{-1}$, nebulizer

555 pressure $44 \mathrm{psi}$, sheath gas temperature $300^{\circ} \mathrm{C}$, sheath gas flow $12 \mathrm{~L} \cdot \mathrm{min}^{-1}$, VCap $3000 \mathrm{~V}$, nozzle

556 voltage 2000 V, Fragmentor 100 V, Skimmer 65 V, Oct 1 RF Vpp 750 V, and m/z range 50 -

557 1700. Data were acquired under continuous reference mass correction at $\mathrm{m} / \mathrm{z} 121.0509$ and

558922.0890 for positive ion mode and $m / z 119.0363$ and 966.0007 for negative ion mode. Samples

559 were randomized prior to analysis. In addition, a quality control sample was injected after every

$56012^{\text {th }}$ sample to monitor signal stability of the instrument.

$561 \quad$ LC/MS analysis of lipid metabolites

An aliquot of $2 \mu \mathrm{L}$ of lipid extract was subjected to LC/MS analysis by using an Agilent 1290 Infinity II LC-system coupled to an Agilent 6545 Q-TOF mass spectrometer with a dual

HSS T3 column $(2.1 \times 150 \mathrm{~mm}, 1.8 \mu \mathrm{m})$ including an Acquity UPLC® HSS T3 VanGuard Pre-

566 Column $(2.1 \times 5 \mathrm{~mm}, 1.8 \mu \mathrm{m})$ at a temperature of $60^{\circ} \mathrm{C}$ and a flow rate of $250 \mu \mathrm{L} \cdot \mathrm{min}^{-1}$. The

569 formic acid, $10 \mathrm{mM}$ ammonium formate (dissolved in $1 \mathrm{~mL}$ water). The following linear gradient 570 was used: $0-2 \mathrm{~min}, 30 \% \mathrm{~B} ; 17 \mathrm{~min}, 75 \% \mathrm{~B} ; 20 \mathrm{~min}, 85 \% ; 23-26 \mathrm{~min}, 100 \% \mathrm{~B} ; 26,30 \% \mathrm{~B}$

571 followed by a re-equilibration phase of $5 \mathrm{~min}$. 
medRxiv preprint doi: https://doi.org/10.1101/2021.02.05.21251173; this version posted February 8, 2021. The copyright holder for this preprint (which was not certified by peer review) is the author/funder, who has granted medRxiv a license to display the preprint in perpetuity.

It is made available under a CC-BY-ND 4.0 International license .

Lipids were detected in positive and negative ion mode with the following source parameters: gas temperature $250^{\circ} \mathrm{C}$, drying gas flow $11 \mathrm{~L} \cdot \mathrm{min}^{-1}$, nebulizer pressure $35 \mathrm{psi}$, sheath gas temperature $300{ }^{\circ} \mathrm{C}$, sheath gas flow $12 \mathrm{~L} \cdot \mathrm{min}^{-1}$, VCap $3000 \mathrm{~V}$, nozzle voltage $500 \mathrm{~V}$, Fragmentor $160 \mathrm{~V}$, Skimmer 65 V, Oct 1 RF Vpp 750 V, and m/z range 50-1700. Data were acquired under continuous reference mass correction at $\mathrm{m} / \mathrm{z} 121.0509$ and 922.0890 in positive ion mode and $\mathrm{m} / \mathrm{z} 119.0363$ and 966.0007 in negative ion mode. Samples were randomized before analysis. In addition, a quality control sample was injected after every $12^{\text {th }}$ sample to monitor signal stability of the instrument.

\section{Data preprocessing and normalization}

Polar metabolite identifications were supported by matching the retention time, accurate mass, and MS/MS fragmentation data to our in-house retention time and MS/MS library created from authentic reference standards (Mass Spectrometry Metabolite Library supplied by IROA Technologies, Millipore Sigma, St. Louis, MO, USA) and online MS/MS libraries (Human Metabolome Database (HMDB, https://hmdb.ca, (Wishart et al., 2018)), Mass Bank of North America (MoNA, https://mona.fiehnlab.ucdavis.edu/, (Horai et al., 2010)), and mzCloud (https://mzcloud.org). Lipid iterative MS/MS data were annotated with the Agilent Lipid Annotator software. All data files were then analyzed in Skyline (Version 20.1.0.155) to obtain peak areas. $\mathrm{m} / \mathrm{z}$ values of the metabolite and lipid target lists obtained from the metabolite identification workflow, which had at least an MS/MS match to an online library, were extracted under consideration of retention times.

Due to the risk of handling plasma samples from SARS-CoV-2 positive patients and not knowing how many batches of samples we would receive, we refrained from preparing a pooled sample and instead used the NIST SRM 1950 plasma reference material as quality control (QC) 
medRxiv preprint doi: https://doi.org/10.1101/2021.02.05.21251173; this version posted February 8, 2021. The copyright holder for this preprint (which was not certified by peer review) is the author/funder, who has granted medRxiv a license to display the preprint in perpetuity.

It is made available under a CC-BY-ND 4.0 International license .

595

596

597

598

599

600

601

602

603

604

605

606

607

608

609

610

611

612

613

614

615

616

sample in each batch. The QC sample was injected after every $12^{\text {th }}$ sample. After peak area extraction, batch effects were observed in the research samples (see Figure S2a). The research samples and QC data were used to test typical batch normalization methods (see Figure S2b) including constant sum, unit length, scale, percentile shift, minimum-maximum, PQN, quantile and ComBat correction used in metabolomics (Chong et al., 2018; Di Guida et al., 2016;

Fernández-Albert et al., 2014; Ghosh, 2017; Johnson et al., 2007). In Figure S2b, the variance remaining in the research samples normalized to the variance in the QC samples is shown for each method. The higher this ratio, the more variance remains in the research samples and the more batch derived variance in the QC samples is reduced. ComBat correction outperformed the other batch correction approaches tested using this metric. After correction, samples are well clustered according to sample type (WU-350, QC, blank) as shown in Figure S2c. Importantly, within the research samples, there is no clustering by batch (see Figure S2d).

\section{Animal Studies}

All studies were performed at Mount Sinai School of Medicine. Outbred female LVG golden Syrian hamsters were sourced from Charles River Laboratories (Kingston, NY). The hamsters were anesthetized by intraperitoneal injection of a mixture of ketamine and xylazine prior to intranasal inoculation with $0.1 \mathrm{~mL}$ of $1 \mathrm{e} 5$ plaque-forming units (PFU) of SARS-CoV-2 (WA-1) or H1N1 influenza A virus (A/California/04/2009). On day 2, 4, 6, and 14 days post-infection, 36 anesthetized hamsters per infection group were euthanized by exsanguination followed by intracardiac injection of veterinary euthanasia solution (SleepAway; Fort Dodge). Plasma samples were treated by exposure to germicidal UV-C light. 
medRxiv preprint doi: https://doi.org/10.1101/2021.02.05.21251173; this version posted February 8, 2021. The copyright holder for this preprint (which was not certified by peer review) is the author/funder, who has granted medRxiv a license to display the preprint in perpetuity.

It is made available under a CC-BY-ND 4.0 International license .

\section{Study Approval}

Portions of the human study relevant to Barnes Jewish Hospital, Christian Hospital, and Washington University were reviewed and approved by the Washington University in Saint Louis Institutional Review Board (WU-350 study approval \#202003085, and plasma metabolomics study approval \#202004204). All animal studies were approved by the Institutional Care and Use Committee at Mount Sinai School of Medicine, following the humane care and use guidelines set by the institution.

\section{Machine Learning}

Samples were split into two distinct cohorts for training and testing the ML model. D0 $\mathrm{COV}+$ patient samples within batches 1-6 made up the training set and $\mathrm{d} 0 \mathrm{COV}+$ patient samples from batches 7 through 9 made up the test set. Training and tests sets were treated independently except for batch normalization which was carried out for all patients (including samples collected after d0 and COV-samples) together. Demographics of both training and tests sets are available in Table S1 and Table S2.

Model selection was based on 20 -fold cross validation of the training set. Five different ML models: logistic regression, ElasticNet linear regression, partial least squares discriminant analysis (PLSDA), support vector machine (SVM), and random forest were selected for consideration based on interpretability and previous studies (Fraser et al., 2020; Lalmuanawma et al., 2020; Mendez et al., 2019; Shen et al., 2020). Hyperparameters of all models and feature selection strategies were optimized using 20 -fold cross validation and a grid search. Two separate feature selection strategies were tested: a correlation-based approach and a statisticbased approach. In the correlation-based approach, the Pearson correlation was computed between each metabolite's intensity and the disease severity. Then, the top $X \%$ of metabolites 
medRxiv preprint doi: https://doi.org/10.1101/2021.02.05.21251173; this version posted February 8, 2021. The copyright holder for this preprint (which was not certified by peer review) is the author/funder, who has granted medRxiv a license to display the preprint in perpetuity.

It is made available under a CC-BY-ND 4.0 International license.

640

641

642

643

644

645

646

647

648

649

650

651

652

653

654

655

656

657

658

659

660

661

sorted by absolute correlation were taken as the predictors for the ML model. In the statisticbased approach, a student's t-test was performed to assess the statistical significance of the differences in each metabolite's intensity between $\mathrm{COV}+$ severe and $\mathrm{COV}+$ non-severe patients. Absolute fold-change and p-value cutoffs were used to select metabolites. Performance was assessed with the area under the receiver operating characteristic curve (AUC). After optimization, ElasticNet regression achieved the highest AUC on the cross validated training dataset. The ElasticNet model is given below in Equation 1 where $X$ is matrix of metabolic profiles (\# of samples $\mathrm{x}$ \# of metabolites), $b$ is the bias term, $y$ is the sample labels $(0=\mathrm{COV}+$ non-severe, $1=\mathrm{COV}+$ severe), $w$ is the weight of each metabolite to the model prediction, $\alpha$ is the weight of the regularization, and $\rho$ is the mixing parameter between the $l_{1}$ and $l_{2}$ norm regularization.

$$
\min _{w} \frac{1}{2 n}\|X w+b-y\|_{2}+\alpha \rho\|w\|_{1}+\frac{\alpha(1-\rho)}{2}\|w\|_{2}^{2}
$$

After optimization, the correlation-based feature selection was used taking the top 33\% most correlated metabolites with model hyperparameters $\alpha=10.0$ and $\rho=0.0$. In the reduced predictor model, no feature selection was performed and model hyperparameters $\alpha=1.0$ and $\rho=0.0$ were used.

The variable importance of each metabolite in the ElasticNet model is easily computed from the optimized weights, $w$. To normalize for the different abundances of the metabolites, each weight was normalized by the median abundance of the metabolite across all samples. The more positive the variable importance, the more predictive that metabolite is to severe disease. The more negative the variable importance, the more predictive the metabolite is to non-severe disease. To find the metabolites that significantly contribute to the model fit, the training dataset 
medRxiv preprint doi: https://doi.org/10.1101/2021.02.05.21251173; this version posted February 8, 2021. The copyright holder for this preprint (which was not certified by peer review) is the author/funder, who has granted medRxiv a license to display the preprint in perpetuity.

It is made available under a CC-BY-ND 4.0 International license .

662 was resampled with replacement 10,000 times. At each iteration, the ElasticNet model was

663 trained and the variable importance was calculated. After the iterations were complete, the $95 \%$

664 confidence interval of the variable importance was calculated for each metabolite using the 2.5

665 and 97.5 percentiles. If this interval included zero, the metabolite did not significantly contribute

666 to the model fit.

667

All ML analyses were carried out using Python (v3.7) with extensive use of the packages

668 SciPy (v1.4.1) (Virtanen et al., 2020a) and Scikit-learn (v0.23.1) (Pedregosa et al., 2011).

669 Code availability

670 Custom code used to perform the ML analyses is available on GitHub (https://github.com/e-

671 stan/covid_19_analysis)

672

Data availability

673

The raw LC/MS data as well as the processed metabolic profiles and their corresponding

674 deidentified metadata for the human and animal samples will be made publicly available on the

675 Metabolomics Workbench repository.

676

Statistical analysis

677

All statistical analyses were performed using the SciPy (v1.4.1) (Virtanen et al., 2020b) and

678

statsmodels (v0.11.1) (Seabold and Perktold, 2010) Python packages and with the Mass Profiler

679 Professional Software (Agilent Technologies, v15.5). All p-values were corrected for multiple

680 hypothesis testing using the Benjamini-Hochberg procedure (Benjamini and Hochberg, 1995).

681

682

683

\section{Permutation test}

To assess the significance of the model fit and compare the predictive power to what is expected from random chance, we performed a permutation test. After the feature selection and 
medRxiv preprint doi: https://doi.org/10.1101/2021.02.05.21251173; this version posted February 8, 2021. The copyright holder for this preprint (which was not certified by peer review) is the author/funder, who has granted medRxiv a license to display the preprint in perpetuity.

It is made available under a CC-BY-ND 4.0 International license .

model hyperparameters were optimized, the training dataset labels were permuted, and the model was retrained on the permuted data. Then, the performance of this model was assessed on the non-permuted test set and the AUC was computed. This process was repeated 1,000 times. The empirical p-value was computed by calculating the percentage of the 1,000 permutations that achieved an AUC higher than that of the model's performance when trained on non-permuted data.

\section{Confirming metabolite identities of predictor metabolites}

The identities of the 25 predictor metabolites were rigorously confirmed with authentic standards. For the polar compounds, authentic standards were purchased to not only match MS/MS but also retention times for identification. For lipids, one or two standards per lipid class were matched to an authentic standard to compare MS/MS spectra and retention times. PCs were identified based on $\mathrm{m} / \mathrm{z}$ and the two characteristic fragments 184.0733 and 86.0964 in positive ionization mode. For PCs where no peaks for the acyl-chains were observed, only the sum composition can be given. LPE 18:0 was matched to its authentic standard based on retention time and MS/MS spectra. PEs were identified based on the neutral loss of phosphorylethanolamine (141.0191) in positive mode. The fatty acyl composition could be derived from the spectra, but no differentiation of regioisomers was possible, as was the case for ceramides. To denote regiospecificity, metabolites whose regioisomers could be differentiated have their acyl-chains are separated with a "/" while those that could not have a " ". Cer-NS d18:1_16:0 was matched to its authentic standard. Cer-NS d18:2_16:0 matched the MS/MS library spectrum and eluted slightly before Cer-NS d18:1_16:0 as expected due to having one less double bond. LPCs were identified based on MS/MS spectral matches. Standards were available for LPC 14:0/0:0 and LPC 18:1/0:0. Their retention times were used as a reference for 
medRxiv preprint doi: https://doi.org/10.1101/2021.02.05.21251173; this version posted February 8, 2021. The copyright holder for this preprint (which was not certified by peer review) is the author/funder, who has granted medRxiv a license to display the preprint in perpetuity.

It is made available under a CC-BY-ND 4.0 International license .

the other LPCs. The two regioisomers of LPCs (sn1 and sn2) were separated by liquid chromatography, with the sn1 isomer eluting later. They are also distinguished by their MS/MS spectra. 1-acyl-LPC (sn1) shows two main fragments $(\mathrm{m} / \mathrm{z} 184.0733$ and 104.1070), whereas the 2-acyl-LPC (sn2) has a more pronounced 184.0733 fragment. The 104.1070 fragment (choline) has been previously reported as being more abundant from LPCs with the fatty acid chain in the sn1 position from the sodium adducts when studying the lysophospholipid regioisomers (Han and Gross, 1996). We note that sn2 LPCs can be converted to sn1 during sample preparation, and our sample preparation was not dedicated to preserve those isomers (Koistinen et al., 2015; Okudaira et al., 2014).

\section{Acquiring MS/MS data}

MS/MS spectra for polar metabolites were acquired on an Orbitrap ID-X Tribrid mass spectrometer (Thermo Scientific). A Vanquish Horizon UHPLC system, with the same chromatographic conditions as described in the Methods, was interfaced with the mass spectrometer via electrospray ionization in both positive and negative mode with a spray voltage of 3.5 and $2.8 \mathrm{kV}$, respectively. The RF lens value was $35 \%$. Data were acquired in data dependent acquisition (DDA) mode using the built-in deep scan option (AcquireX) with a mass range of $67-900 \mathrm{~m} / \mathrm{z}$. MS/MS scans were acquired at $15 \mathrm{~K}$ resolution on a NIST SRM 1950 plasma sample from and 4 individual samples from $\mathrm{d} 0, \mathrm{~d} 3, \mathrm{~d} 7$, and $\mathrm{d} 14$ in both positive and negative polarity with different collision energies in the range of $20 \mathrm{NCE}$ to $50 \mathrm{NCE}$ for HCD and 30 NCE for CID to maximize identifications.

MS/MS spectra for polar metabolites and lipids were acquired using an iterative approach in the MassHunter Acquisition Software (Version 10.1.48, Agilent Technologies) on an Agilent 6540 and 6545 QTOF respectively. The same source settings as for MS1 data acquisition were 
medRxiv preprint doi: https://doi.org/10.1101/2021.02.05.21251173; this version posted February 8, 2021. The copyright holder for this preprint (which was not certified by peer review) is the author/funder, who has granted medRxiv a license to display the preprint in perpetuity.

It is made available under a CC-BY-ND 4.0 International license .

used. MS/MS spectra were acquired at a scan rate of 3 spectra/s with different intensity thresholds and collision energies of 10,20 , and $40 \mathrm{~V}$ to increase identification rates.

Acknowledgements: This work was supported by funding from the National Institutes of Health grants R24OD024624 (G.J.P.) and R35ES2028365 (G.J.P.). This study utilized samples obtained from the Washington University School of Medicine's COVID-19 biorepository, which is supported by: the Barnes-Jewish Hospital Foundation; the Siteman Cancer Center grant P30 CA091842 from the National Cancer Institute of the National Institutes of Health; and the Washington University Institute of Clinical and Translational Sciences grant UL1TR002345 from the National Center for Advancing Translational Sciences of the National Institutes of Health. The content is solely the responsibility of the authors and does not necessarily represent the view of the NIH. For their work in the development and maintenance of the COVID-19 biorepository, we would like to thank Jane O’Halloran, $\mathrm{MD}, \mathrm{PhD}$; Charles Goss, $\mathrm{PhD}$, and Phillip Mudd, MD, PhD. This work was also partly supported by CRIP (Center for Research for Influenza Pathogenesis), a NIAID supported Center of Excellence for Influenza Research and Surveillance (CEIRS, contract HHSN272201400008C; WCL, RAA, and AGS); by NIAID grant U19AI135972; by NCI grant U54CA260560; by supplements to NIAID grants U19AI135972, U19AI142733 and DoD grant W81XWH-20-1-0270; by the Defense Advanced Research Projects Agency (HR0011-19-2-0020); by the generous support of the JPB Foundation and the Open Philanthropy Project (research grant 2020-215611 (5384); and by anonymous donors (A.G.S.).

Author contributions: M.S. planned the metabolomics study, executed the sample preparation, acquired and analyzed the LC/MS and MS/MS data, did statistical analysis, prepared figures, and 
medRxiv preprint doi: https://doi.org/10.1101/2021.02.05.21251173; this version posted February 8, 2021. The copyright holder for this preprint (which was not certified by peer review) is the author/funder, who has granted medRxiv a license to display the preprint in perpetuity.

It is made available under a CC-BY-ND 4.0 International license .

753 wrote the manuscript. E.S. analyzed the data, did the statistical analysis, developed the prediction

754 model, prepared figures, and wrote the manuscript. M.S.-H. executed the sample preparation,

755 acquired and analyzed the LC/MS and MS/MS data, prepared figures, and contributed to writing

756 the manuscript. D.S.A. planned the metabolomics study and collected and managed demographic

757 and clinical information. R.A., W.-C.L., K.A.T., L.P.S and A.G.S. planned the hamster study and

758 collected the samples and prepared the hamster samples for metabolomics. G.J.P. planned the

759 study, helped design experiments, and supervised all aspects of the research. All authors

760 contributed to revising the manuscript.

761 Competing interests: The AG-S laboratory has received research support from Pfizer,

762 Pharmamar, Blade Therapeutics, Avimex, Dynavax, Kenall Manufacturing, ImmunityBio,

763 Nanocomposix, Senhwa Biosciences and 7Hills Pharma. AG-S has consulting agreements for the

764 following companies involving cash and/or stock: Vivaldi Biosciences, Contrafect, 7 Hills

765 Pharma, Avimex, Vaxalto, Accurius and Esperovax. G.J.P. is a scientific advisor for Cambridge

766 Isotope Laboratories. All other authors declare no conflicts of interest. 
medRxiv preprint doi: https://doi.org/10.1101/2021.02.05.21251173; this version posted February 8, 2021. The copyright holder for this preprint (which was not certified by peer review) is the author/funder, who has granted medRxiv a license to display the preprint in perpetuity.

It is made available under a CC-BY-ND 4.0 International license .

\section{References}

(2020a). HHS Allocates Regeneron Therapeutic to Treat Patients With Mild to Moderate COVID-19 (available at https://www.hhs.gov/).

(2020b). https://www.phe.gov/emergency/events/COVID19/investigationMCM/Bamlanivimab/Pages/allocation.aspx. In US Department of Health \& Human Services (Office of the Assistant Secretary for Preparedness and Response).

(2020c). https://www.phe.gov/emergency/events/COVID19/investigation-MCM/cas imd/Pages/allocation.aspx. In US Department of Health \& Human Services (Office of the Assistant Secretary for Preparedness and Response).

(2020d). John Hopkins Coronavirus Resource Center (available at https://coronavirus.jhu.edu/about).

Ahmed, Z., Zeeshan, S., Foran, D.J., Kleinman, L.C., Wondisford, F.E., and Dong, X. (2020). Integrative clinical, genomics and metabolomics data analysis for mainstream precision medicine to investigate COVID-19. BMJ Innovations, bmjinnov-2020-000444.

Arunachalam, P.S., Wimmers, F., Mok, C.K.P., Perera, R., Scott, M., Hagan, T., Sigal, N., Feng, Y., Bristow, L., Tak-Yin Tsang, O., et al. (2020). Systems biological assessment of immunity to mild versus severe COVID-19 infection in humans. Science 369, 1210-1220.

Beger, R.D., Dunn, W., Schmidt, M.A., Gross, S.S., Kirwan, J.A., Cascante, M., Brennan, L., Wishart, D.S., Oresic, M., Hankemeier, T., et al. (2016). Metabolomics enables precision medicine: "A White Paper, Community Perspective". Metabolomics : Official journal of the Metabolomic Society 12, 149-149.

Benesty, J., Chen, J., Huang, Y., and Cohen, I. (2009). Noise Reduction in Speech Processing, Vol 2 (SpringerVerlag Berlin Heidelberg).

Benjamini, Y., and Hochberg, Y. (1995). Controlling the False Discovery Rate: A Practical and Powerful Approach to Multiple Testing. Journal of the Royal Statistical Society Series B (Methodological) 57, 289-300.

CDC (2020). Coronavirus Disease 2019 (COVID-19) - SymptomsCenters for Disease Control and Prevention (available at https://www.cdc.gov/coronavirus/2019-ncov/symptoms-testing/symptoms.html).

Chan, J.F., Zhang, A.J., Yuan, S., Poon, V.K., Chan, C.C., Lee, A.C., Chan, W.M., Fan, Z., Tsoi, H.W., Wen, L., et al. (2020). Simulation of the Clinical and Pathological Manifestations of Coronavirus Disease 2019 (COVID-19) in a Golden Syrian Hamster Model: Implications for Disease Pathogenesis and Transmissibility. Clin Infect Dis 71, 2428-2446.

Chong, J., Soufan, O., Li, C., Caraus, I., Li, S., Bourque, G., Wishart, D.S., and Xia, J. (2018). MetaboAnalyst 4.0: towards more transparent and integrative metabolomics analysis. Nucleic Acids Res 46, W486-W494.

Conlen F., K.J., Leatherby L., Smart C. (2021). How Full Are Hospital I.C.U.s Near You? The New York Times.

Di Guida, R., Engel, J., Allwood, J.W., Weber, R.J., Jones, M.R., Sommer, U., Viant, M.R., and Dunn, W.B. (2016). Non-targeted UHPLC-MS metabolomic data processing methods: a comparative investigation of normalisation, missing value imputation, transformation and scaling. Metabolomics 12, 93.

FDA (2020). Fact sheet for health care providers emergency use authorization (EUA) of casirivimab and imdevimab (available at https://www.fda.gov/media/143892/download).

Fernández-Albert, F., Llorach, R., Garcia-Aloy, M., Ziyatdinov, A., Andres-Lacueva, C., and Perera, A. (2014). Intensity drift removal in LC/MS metabolomics by common variance compensation. Bioinformatics 30, 2899-2905.

Fraser, D.D., Slessarev, M., Martin, C.M., Daley, M., Patel, M.A., Miller, M.R., Patterson, E.K., O'Gorman, D.B., Gill, S.E., Wishart, D.S., et al. (2020). Metabolomics Profiling of Critically Ill Coronavirus Disease 2019 Patients: Identification of Diagnostic and Prognostic Biomarkers. Crit Care Explor 2, e0272.

Gagnebin, Y., Jaques, D.A., Rudaz, S., de Seigneux, S., Boccard, J., and Ponte, B. (2020). Exploring blood alterations in chronic kidney disease and haemodialysis using metabolomics. Sci Rep 10, 19502. 
Ghosh, D. (2017). Statistical Analysis of Proteomics, Metabolomics, and Lipidomics Data Using Mass Spectrometry

Susmita Datta and Bart J. A. Mertens Springer Frontiers in Probability and the Statistical Sciences, 2017, 295 pages, $£ 82.00$, hardcover ISBN: 978-3-319-45807-6. International Statistical Review 85, 544-545.

Goyal, P., Choi, J.J., Pinheiro, L.C., Schenck, E.J., Chen, R., Jabri, A., Satlin, M.J., Campion, T.R., Jr., Nahid, M., Ringel, J.B., et al. (2020). Clinical Characteristics of Covid-19 in New York City. N Engl J Med 382, 2372-2374.

Han, X., and Gross, R.W. (1996). Structural Determination of Lysophospholipid Regioisomers by Electrospray Ionization Tandem Mass Spectrometry†. Journal of the American Chemical Society 118, 451-457.

Horai, H., Arita, M., Kanaya, S., Nihei, Y., Ikeda, T., Suwa, K., Ojima, Y., Tanaka, K., Tanaka, S., Aoshima, K., et al. (2010). MassBank: a public repository for sharing mass spectral data for life sciences. J Mass Spectrom 45, 703714.

Hou, Y.J., Okuda, K., Edwards, C.E., Martinez, D.R., Asakura, T., Dinnon, K.H., 3rd, Kato, T., Lee, R.E., Yount, B.L., Mascenik, T.M., et al. (2020). SARS-CoV-2 Reverse Genetics Reveals a Variable Infection Gradient in the Respiratory Tract. Cell 182, 429-446 e414.

Imai, M., Iwatsuki-Horimoto, K., Hatta, M., Loeber, S., Halfmann, P.J., Nakajima, N., Watanabe, T., Ujie, M., Takahashi, K., Ito, M., et al. (2020). Syrian hamsters as a small animal model for SARS-CoV-2 infection and countermeasure development. Proc Natl Acad Sci U S A 117, 16587-16595.

Iwatsuki-Horimoto, K., Nakajima, N., Ichiko, Y., Sakai-Tagawa, Y., Noda, T., Hasegawa, H., and Kawaoka, Y. (2018). Syrian Hamster as an Animal Model for the Study of Human Influenza Virus Infection. J Virol 92.

Jain, V., and Yuan, J.M. (2020). Predictive symptoms and comorbidities for severe COVID-19 and intensive care unit admission: a systematic review and meta-analysis. Int J Public Health 65, 533-546.

Johnson, W.E., Li, C., and Rabinovic, A. (2007). Adjusting batch effects in microarray expression data using empirical Bayes methods. Biostatistics 8, 118-127.

Kattan, M.W., Ji, X., Milinovich, A., Adegboye, J., Duggal, A., Dweik, R., Khouli, H., Gordon, S., Young, J.B., and Jehi, L. (2020). An Algorithm for Classifying Patients Most Likely to Develop Severe Coronavirus Disease 2019 Illness. Critical Care Explorations 2.

Kim, P.S., Read, S.W., and Fauci, A.S. (2020). Therapy for Early COVID-19: A Critical Need. JAMA 324, 21492150 .

Kimhofer, T., Lodge, S., Whiley, L., Gray, N., Loo, R.L., Lawler, N.G., Nitschke, P., Bong, S.H., Morrison, D.L., Begum, S., et al. (2020). Integrative Modeling of Quantitative Plasma Lipoprotein, Metabolic, and Amino Acid Data Reveals a Multiorgan Pathological Signature of SARS-CoV-2 Infection. J Proteome Res 19, 4442-4454.

Koistinen, K.M., Suoniemi, M., Simolin, H., and Ekroos, K. (2015). Quantitative lysophospholipidomics in human plasma and skin by LC-MS/MS. Anal Bioanal Chem 407, 5091-5099.

Lalmuanawma, S., Hussain, J., and Chhakchhuak, L. (2020). Applications of machine learning and artificial intelligence for Covid-19 (SARS-CoV-2) pandemic: A review. Chaos Solitons Fractals 139, 110059.

Liao, M., Liu, Y., Yuan, J., Wen, Y., Xu, G., Zhao, J., Cheng, L., Li, J., Wang, X., Wang, F., et al. (2020). Singlecell landscape of bronchoalveolar immune cells in patients with COVID-19. Nat Med 26, 842-844.

Luo, X., Zhou, W., Yan, X., Guo, T., Wang, B., Xia, H., Ye, L., Xiong, J., Jiang, Z., Liu, Y., et al. (2020). Prognostic Value of C-Reactive Protein in Patients With Coronavirus 2019. Clin Infect Dis 71, 2174-2179.

Mendez, K.M., Broadhurst, D.I., and Reinke, S.N. (2020). Migrating from partial least squares discriminant analysis to artificial neural networks: a comparison of functionally equivalent visualisation and feature contribution tools using jupyter notebooks. Metabolomics 16, 17.

Mendez, K.M., Reinke, S.N., and Broadhurst, D.I. (2019). A comparative evaluation of the generalised predictive ability of eight machine learning algorithms across ten clinical metabolomics data sets for binary classification. Metabolomics 15, 150 . 
Migaud, M., Gandotra, S., Chand, H.S., Gillespie, M.N., Thannickal, V.J., and Langley, R.J. (2020). Metabolomics to Predict Antiviral Drug Efficacy in COVID-19. Am J Respir Cell Mol Biol 63, 396-398.

Mudd, P.A., Crawford, J.C., Turner, J.S., Souquette, A., Reynolds, D., Bender, D., Bosanquet, J.P., Anand, N.J., Striker, D.A., Martin, R.S., et al. (2020). Distinct inflammatory profiles distinguish COVID-19 from influenza with limited contributions from cytokine storm. Sci Adv 6.

Muñoz-Fontela, C., Dowling, W.E., Funnell, S.G.P., Gsell, P.S., Riveros-Balta, A.X., Albrecht, R.A., Andersen, H., Baric, R.S., Carroll, M.W., Cavaleri, M., et al. (2020). Animal models for COVID-19. Nature 586, 509-515.

Okudaira, M., Inoue, A., Shuto, A., Nakanaga, K., Kano, K., Makide, K., Saigusa, D., Tomioka, Y., and Aoki, J. (2014). Separation and quantification of 2-acyl-1-lysophospholipids and 1-acyl-2-lysophospholipids in biological samples by LC-MS/MS. J Lipid Res 55, 2178-2192.

Overmyer, K.A., Shishkova, E., Miller, I.J., Balnis, J., Bernstein, M.N., Peters-Clarke, T.M., Meyer, J.G., Quan, Q., Muehlbauer, L.K., Trujillo, E.A., et al. (2020). Large-Scale Multi-omic Analysis of COVID-19 Severity. Cell Syst.

Park, J.H., and Lee, H.K. (2020). Re-analysis of Single Cell Transcriptome Reveals That the NR3C1-CXCL8Neutrophil Axis Determines the Severity of COVID-19. Front Immunol 11, 2145.

Patti, G.J., Yanes, O., and Siuzdak, G. (2012). Innovation: Metabolomics: the apogee of the omics trilogy. Nat Rev Mol Cell Biol 13, 263-269.

Pedregosa, F., Varoquaux, G., Gramfort, A., Michel, V., Thirion, B., Grisel, O., Blondel, M., Prettenhofer, P., Weiss, R., Dubourg, V., et al. (2011). Scikit-learn: Machine Learning in Python. J Mach Learn Res 12, 2825-2830.

Petrilli, C.M., Jones, S.A., Yang, J., Rajagopalan, H., O'Donnell, L., Chernyak, Y., Tobin, K.A., Cerfolio, R.J., Francois, F., and Horwitz, L.I. (2020). Factors associated with hospital admission and critical illness among 5279 people with coronavirus disease 2019 in New York City: prospective cohort study. BMJ 369, m1966.

Seabold, S., and Perktold, J. (2010). (Austin, Texas).

Shen, B., Yi, X., Sun, Y., Bi, X., Du, J., Zhang, C., Quan, S., Zhang, F., Sun, R., Qian, L., et al. (2020). Proteomic and Metabolomic Characterization of COVID-19 Patient Sera. Cell 182, 59-72 e15.

Smith, S.M., Boppana, A., Traupman, J.A., Unson, E., Maddock, D.A., Chao, K., Dobesh, D.P., Brufsky, A., and Connor, R.I. (2020). Impaired glucose metabolism in patients with diabetes, prediabetes, and obesity is associated with severe COVID-19. J Med Virol.

Song, J.W., Lam, S.M., Fan, X., Cao, W.J., Wang, S.Y., Tian, H., Chua, G.H., Zhang, C., Meng, F.P., Xu, Z., et al. (2020). Omics-Driven Systems Interrogation of Metabolic Dysregulation in COVID-19 Pathogenesis. Cell Metab $32,188-202$ e185.

Tate, R.F. (1954). Correlation Between a Discrete and a Continuous Variable. Point-Biserial Correlation. Ann Math Statist 25, 603-607.

Thomas, T., Stefanoni, D., Reisz, J.A., Nemkov, T., Bertolone, L., Francis, R.O., Hudson, K.E., Zimring, J.C., Hansen, K.C., Hod, E.A., et al. (2020). COVID-19 infection alters kynurenine and fatty acid metabolism, correlating with IL-6 levels and renal status. JCI Insight 5.

Virtanen, P., Gommers, R., Oliphant, T.E., Haberland, M., Reddy, T., Cournapeau, D., Burovski, E., Peterson, P., Weckesser, W., Bright, J., et al. (2020a). Author Correction: SciPy 1.0: fundamental algorithms for scientific computing in Python. Nat Methods 17, 352.

Virtanen, P., Gommers, R., Oliphant, T.E., Haberland, M., Reddy, T., Cournapeau, D., Burovski, E., Peterson, P., Weckesser, W., Bright, J., et al. (2020b). SciPy 1.0: fundamental algorithms for scientific computing in Python. Nature methods 17, 261-272.

Wishart, D.S., Feunang, Y.D., Marcu, A., Guo, A.C., Liang, K., Vázquez-Fresno, R., Sajed, T., Johnson, D., Li, C., Karu, N., et al. (2018). HMDB 4.0: the human metabolome database for 2018. Nucleic Acids Res 46, D608-D617.

Wu, D., Shu, T., Yang, X., Song, J.-X., Zhang, M., Yao, C., Liu, W., Huang, M., Yu, Y., Yang, Q., et al. (2020a). Plasma metabolomic and lipidomic alterations associated with COVID-19. National Science Review 7, 1157-1168. 
medRxiv preprint doi: https://doi.org/10.1101/2021.02.05.21251173; this version posted February 8, 2021. The copyright holder for this preprint (which was not certified by peer review) is the author/funder, who has granted medRxiv a license to display the preprint in perpetuity.

It is made available under a CC-BY-ND 4.0 International license .

902 Wu, F., Zhao, S., Yu, B., Chen, Y.M., Wang, W., Song, Z.G., Hu, Y., Tao, Z.W., Tian, J.H., Pei, Y.Y., et al.

903 (2020b). A new coronavirus associated with human respiratory disease in China. Nature 579, $265-269$.

904 Yang, L., Liu, S., Liu, J., Zhang, Z., Wan, X., Huang, B., Chen, Y., and Zhang, Y. (2020). COVID-19:

905 immunopathogenesis and Immunotherapeutics. Signal Transduct Target Ther 5, 128.

906 Zhang, H., Penninger, J.M., Li, Y., Zhong, N., and Slutsky, A.S. (2020). Angiotensin-converting enzyme 2 (ACE2)

907 as a SARS-CoV-2 receptor: molecular mechanisms and potential therapeutic target. Intensive Care Med 46, 586-

908590.

909 Zhou, P., Yang, X.L., Wang, X.G., Hu, B., Zhang, L., Zhang, W., Si, H.R., Zhu, Y., Li, B., Huang, C.L., et al. 910 (2020). A pneumonia outbreak associated with a new coronavirus of probable bat origin. Nature 579, $270-273$.

911 Zou, H., and Hastie, T. (2005). Regularization and Variable Selection via the Elastic Net. Journal of the Royal 912 Statistical Society Series B (Statistical Methodology) 67, 301-320.

913

914 